\title{
Refugiados y evacuados de la provincia de Toledo al comienzo de la guerra civil (1936) ${ }^{1}$
}

\author{
Juan Carlos Collado \\ Investigador. Fundación Francisco Largo Caballero, Madrid \\ Refugees and evacues of the province of Toledo \\ at the outbreak of the civil war (1936)
}

\begin{abstract}
RESUMEN
Desde el comienzo de la guerra civil tuvieron lugar movimientos forzosos de población al compás del avance de los frentes. Como ya sucedió en Andalucía y Extremadura, las sucesivas derrotas del ejército republicano en las comarcas septentrionales de la provincia de Toledo provocaron de nuevo desplazamientos masivos de población con Madrid como destino principal. Empezaba el drama de los refugiados.

\section{PALABRAS CLAVES}

Guerra civil. Ejército de África. Frente de Extremadura. Frente del Tajo y Sector del Centro. Éxodo, Pueblos despoblados, desplazados, refugiados y evacuados, Madrid, evacuación de Madrid.
\end{abstract}

\begin{abstract}
From the begining of the civil war, forced movements of populations took place witnessing the avance of the army detachments. As it already happened in Andalucia and Extremadura, the successive defeats suffered by the recuplican army in the northern regions of the province of Toledo caused other mass movements of civilians towards Madrid as the main destination. It was just the beggining of the refugees tragedy
KEY WORDS
Civil war. Army of Africa. Extremadura front. Tajo front and the Central Sector. Exodus. Uninhabited villages, displaced civilians, refugees and evacues, Madrid, evacuation of Mafrid.

1 El presente artículo es una síntesis de varios capítulos del trabajo de investigación «Los desplazados de la guerra civil en la provincia de Toledo», dirigido por la profesora Alicia Alted Vigil. Departamento de Historia Contemporánea, UNED. 


\section{INTRODUCCIÓN}

El presente artículo se centra en el ámbito territorial de Toledo y se adentra brevemente en los movimientos migratorios que se produjeron en los pueblos septentrionales de la provincia como consecuencia de las campañas militares del verano y otoño de 1936. No son objeto de este estudio, y esto es importante resaltarlo, las personas que huyeron de la zona controlada por la República y pasaron al lado franquista. Tampoco es materia de este trabajo la dinámica política vivida en estos municipios los meses anteriores a la ocupación, análisis que podría ayudar a explicar la huida de los dirigentes frentepopulistas o de las personas más implicadas con la República, pero no la del grueso de la población civil.

La pretensión primordial de esta investigación es analizar los acontecimientos militares que desencadenaron un importante éxodo en las localidades del norte de Toledo desde finales de agosto de 1936. Los acontecimientos parecen probar que, como ya sucedió en Andalucía occidental y Extremadura, la llegada del ejército de África a la provincia provocó un movimiento de población al compás del avance de los frentes, principalmente en dirección a Madrid. Desde una capital saturada y preparada para el asedio, gran número de estos refugiados fueron distribuidos a su vez a otras localidades de la España republicana.

Uno de los problemas principales para el estudio de la población refugiada es el de su análisis desde el punto de vista cuantitativo. La desorganización inicial de los organismos creados por el ejecutivo republicano para atender a los desplazados, la multiplicidad de los mismos y la falta de medios para la elaboración de censos en los lugares de origen y destino, son causas suficientes para explicar en parte esta dificultad, así como la dispersión de las fuentes. A pesar de la precariedad de la documentación, entendemos que el éxodo producido en el momento inicial de 1936 fue tan intenso que pudo estar entre un tercio y la mitad global de la población, y afectó, en mayor o menor medida, a la totalidad de las localidades toledanas del norte provincial.

Según avanzaban los frentes o se superaban las líneas defensivas se originaban desplazamientos forzosos de población civil. Hubo guerra de propaganda en este sentido con opiniones muy contradictorias. La polémica llegó a la prensa, a la radio y a los informativos de las más importantes productoras del momento que entablaron también su particular "guerra». Para los partidarios de la República, el éxodo se producía por miedo a los bombardeos indiscriminados, por la brutalidad de las tropas de África. Cuando se acercaban los «fascistas» los campesinos huían. Para los sublevados, los evadidos eran personas que se llevaron o fueron arrastradas por «los rojos» en su huida porque «manifestaban que las tropas de España quemarían sus casas y sus ajuares». En todo caso, pueblos enteros quedaron despoblados. Comoquiera que en este artículo las principales fuentes utilizadas para el examen de los desplazados tienen una procedencia nacionalista: publicaciones como la revista Horizontes, los fondos de la Causa Ge- 
neral, las Actas Municipales de pueblos ya ocupados, etc., los comentarios y argumentos vertidos por alcaldes, secretarios e informantes sobre el origen y los motivos del éxodo vivido en 1936 deben de ser contrastados y considerados con las debidas reservas.

Pero ¿qué entendemos por desplazados? ¿Cómo podemos definir a los refugiados? De acuerdo con Alicia Alted, a los evacuados como resultado de un conflicto bélico no se les puede considerar refugiados políticos sino desplazados por la guerra. ${ }^{2}$ En el marco español, la propia normativa republicana trató de fijar el concepto de refugiado. La primera definición, elaborada en 1936, apareció en una orden ministerial de octubre sobre el funcionamiento del recién creado Comité de Refugiados para Madrid y su provincia, en la que se extendía su jurisdicción a:

«(...) todos los refugiados y emigrados (que procedan de los pueblos enclavados en zonas ocupadas por los rebeldes) que no sean hostiles al régimen, carezcan de medios de vida, no estén acogidos por personas de su familia o amistad y hayan salido del lugar de su residencia con permiso de la Autoridad civil o local o de la militar competente, teniendo derecho preferente, para la asistencia social que ha de prestárseles, las mujeres niños ancianos y enfermos».

Mas no fue hasta primeros de marzo de 1937 cuando, ante el crecimiento del problema, se estableció una definición oficial del término ${ }^{3}$.

Independientemente de las restricciones legales que pudiesen tener los vocablos empleados para denominar a los desplazados, a lo largo del texto utilizaremos indistintamente las expresiones y sinónimos que se usaron en la época para referirse a los mismos y, a pesar de ciertas distinciones, en esos años se les llamó, además de refugiados, de muy diversas formas: evacuados, evadidos, emigrados, fugitivos, etc., utilizadas todas ellas generalmente como sinónimo.

A finales del verano de 1936 estaban en la península 20.000 moros y legionarios organizados en columnas de 500 a 1.000 hombres. La denominada «Columna Madrid» quedaba formada por las agrupaciones africanas de Asensio y Castejón; posteriormente se unió también la de Tella. Con estos efectivos, las tropas del ejército de África se adentraron el día 28 de agosto en la provincia de Toledo por Calzada de Oropesa y las Ventas de San Julián. La Columna, al mando primero de Yagüe y después de Varela, atravesó la provincia de oeste a este en dos meses y finalizó su travesía apoderándose el 26 de octubre de El Viso de San Juan; sin embargo, los municipios situados al sur del río Tajo no se ocuparon hasta finales del

2 ALTED, A., La voz de los vencidos. Madrid, Santillana Ediciones, 2005, pág. 30.

3 Para la primera definición de refugiado véase Gaceta de Madrid (GM), n 288, 14-10-36, pág. 328. La definición legal definitiva del término aparece en una orden posterior del Ministerio de Sanidad y Asistencia Social de 2 de marzo de 1937: Gaceta de la República (GR), nº 62, 3-3-37, pág. 1.051. Así, se consideraba refugiado a «toda persona que, sin ser combatiente o varón sano, mayor de veinte años y menor de cuarenta y cinco haya tenido que mudar de residencia por causa de la presente guerra, no sea hostil al régimen, carezca de medios de subsistencia y no esté acogida por otra de su familia y amistad». 
mes de marzo de 1939, al final ya de la guerra civil. ${ }^{4}$ Por lo menos hasta llegar a Toledo, el ejército nacionalista tomó las poblaciones de forma muy violenta y causando importantes estragos. Todo ello provocó el pánico en la población, miedo que se fue transmitiendo por toda la ruta hasta Madrid.

A partir de agosto de 1936, este frente — según la terminología republicanafue posiblemente el de mayor vitalidad de la guerra. Al principio se designaba frente de Extremadura, enseguida pasó a denominarse sector o frente del Tajo y cuando los nacionales llegaron a las inmediaciones de Madrid lo llamaron sector del Centro. ${ }^{5}$ Algunos aspectos de lo que ocurrió en esta fase de la contienda se convierten en objeto de las siguientes páginas. ${ }^{6}$

\section{DE CALZADA DE OROPESA A TALAVERA DE LA REINA.}

Los últimos días de agosto de 1936 las fuerzas del general Riquelme, insuficientes para frenar a las agrupaciones africanas procedentes de Andalucía, se replegaban por la carretera de Extremadura entre Trujillo y Oropesa. La Columna de Tella estaba en Calzada de Oropesa el 28 de agosto. En un intento por controlar la situación, la noche del 28 al 29 de agosto el alto mando de la República ponía al coronel Salafranca a cargo de la "Columna Oropesa» y al mando de la defensa de Talavera pero, cuando se dirigía a presentarse a Riquelme, se encontró con las milicias en retirada. El 30 de agosto se «liberaba» Oropesa. El enfrentamiento armado provocaba una primera oleada de desplazamientos de población en los pueblos de la comarca más occidental de Toledo: la Campana de Oropesa. El día 31 de agosto de 1936 el corresponsal y escritor austriaco Franz Borkenau partía para Talavera de la Reina, localidad donde sospechaba se viviría un momento decisivo porque era el último pueblo de cierta importancia entre Franco y Madrid. Su pluma reflejó el éxodo de la población de la comarca de Talavera: «Todos los pueblos están llenos de campesinos armados, muchos de los cuales no son del pueblo que custodian, sino de otros que ya han ocupado las tropas de Franco. Millares de campesinos han huido al ver que se acercaban". ${ }^{7}$ Pese a la llegada de refuerzos eran tomadas las localidades de Calera y Gamonal.

4 SABÍN, J. M., «Toledo y la guerra» en ORTIZ HERAS, M., (Coord.): La guerra civil en Castilla-La Mancha. Toledo, Biblioteca Añil, 2000, pp. 139-165.

5 Desde el inicio de la contienda, los partes de guerra fueron el relato oficial de las operaciones de uno y otro bando; los del ejército nacional dividían la información en «Ejércitos» y los republicanos en «Frentes» o «Sectores». Partes Oficiales de guerra. 1936-1939, Ejército Nacional, Servicio Histórico Militar. Madrid, tomo I, 1977 y Partes Oficiales de guerra. 1936-1939, Ejército de la República, Servicio Histórico Militar. Madrid, tomo II, 1978.

6 En los siguientes apartados nos hemos centrado en las campañas militares que se desarrollaron por el norte de Toledo y aportamos algunos datos demográficos de vecinos ausentes de sus pueblos pero, por razones de espacio no vamos a entrar, salvo excepciones, en la problemática particular de cada localidad para explicar la evacuación ni tampoco en la represión o razia inicial llevada a cabo por las tropas ocupantes después de la batalla.

7 Revísese SALAS LARRAZÁBAL, R., Historia del Ejército Popular de la República. Madrid, Editora Nacional, 1973, tomo I, pp. 258 y 260-261. La narración del éxodo de la tierra de Talavera procede de BORKENAU, F., El reñidero español. Barcelona, Ediciones Península, 2001, pp. 172-173. 
Los nacionalistas encontraron resistencia en Oropesa, Calzada de Oropesa, Calera y Chozas y Velada. Como explica Gabriel Cardona, ${ }^{8}$ la oposición durante estos primeros días en la provincia resultó variable pero donde se libraron los combates más fuertes fue en el castillo de Oropesa. Allí estaban pertrechados los milicianos y el asalto se realizó cuerpo a cuerpo. La ruta hacia Talavera de la Reina estaba abierta. Con la excepción de los bombardeos de la aviación republicana quedaba el terreno libre y sin defensa. En la operación participaron el comandante Castejón desde Calera y el teniente coronel Asensio desde Gamonal.

A pesar de que la República contaba con más de 6.000 hombres para defender Talavera, la carencia de armamento y la deficiente instrucción militar acabaría, después de dos días, con la desbandada de la tropa entre el caos general. La crónica del $A B C$ de Sevilla se hacía eco del telegrama recibido el día 3 de septiembre en el cuartel general del ejército nacional en Oropesa, redactado en los términos siguientes: "Jefe columna a teniente coronel Yagüe: A las dos y veinte somos dueños de Talavera de la Reina. Comandante Castejón». ${ }^{9}$ Las consecuencias políticas fueron fulminantes. El mismo día 3 por la noche José Giral dimitía como presidente del gobierno y Francisco Largo Caballero tomaba posesión en su lugar.

El testimonio de los que vivieron de forma directa el éxodo de Talavera no coincidía:

"Cuando ya tomaron Talavera, el 3 de septiembre los nacionales, entonces la gente huía porque las tropas nacionales iban avanzando, pues la gente venía de los pueblos diciendo que si los moros, los legionarios, que si esto, que si lo otro...que hacían tanto y cuanto, y eso no era verdad (...) Nos quedamos en el pueblo y entraron las tropas, y claro, yo, que no había hecho nada, pues no se metieron conmigo, pero a los que habían hecho, no les hicieron lo que les tenían que hacer, porque los tenían que haber matado a todos». ${ }^{10}$

Desde que la «Columna Madrid» ocupaba el día 28 de agosto de 1936 el municipio de Calzada de Oropesa hasta la toma de Talavera de la Reina el 3 de septiembre pasó casi una semana. En el transcurso de estas jornadas fueron cayendo, bien en la línea del avance principal bien en operaciones secundarias, todas las localidades de la zona noroccidental de la provincia. A medida que cambiaban los frentes, los campesinos abandonaban los pueblos por miedo a la guerra. Los últimos días de agosto, septiembre y octubre de 1936, es decir, durante los meses

${ }^{8}$ CARDONA, G., «La guerra de las columnas» en CARDONA, G., y FERNÁNDEZ BASTARRECHE, F., La Guerra Militar. Madrid, Historia 16, vol. 1, 1996, pp. 29-82.

9 Sobre la ocupación de Talavera léase nuevamente a CARDONA, G., Op. Cit., pág. 72. Para la crónica de las operaciones en prensa mírese $A B C$, Sevilla, 4-9-36.

10 Testimonio recogido en BULLÓN DE MENDOZA, A., y DE DIEGO, A., Historias orales de la guerra civil. Barcelona, Ariel, 2000, pág. 152. 


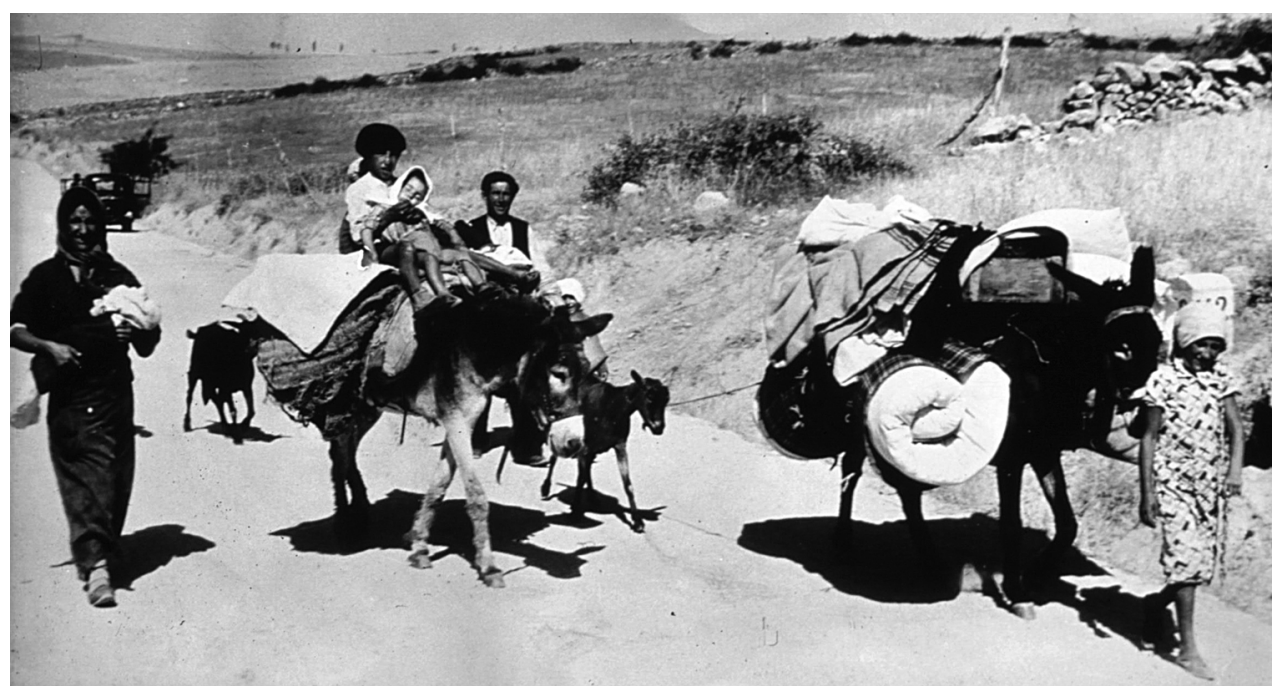

Foto N. ${ }^{\circ}$ 1. Biblioteca Nacional. Guerra Civil. Caja F, Escenas de evacuación.

en que se ocupó la parte septentrional de Toledo, las evacuaciones se llevaron a cabo de forma improvisada y desorganizada. El sistema de evacuación de las poblaciones no se estableció legalmente, mediante orden, hasta marzo de $1937 .{ }^{11} \mathrm{De}$ acuerdo con el itinerario anterior, analizaremos lo que sucedió, demográficamente hablando, e intentaremos cuantificar, siempre que las fuentes consultadas lo permitan, el número de vecinos ausentes de los pueblos objeto de análisis. ${ }^{12}$

11 A partir de marzo de 1937, la competencia para declarar a una población en situación de evacuable pasó al delegado del Ministerio de Guerra de la Oficina Central de Evacuación y Asistencia a Refugiados (OCEAR). Para ello se crearon los «Equipos Ambulantes de Evacuación» que trabajaban con las autoridades de la población a evacuar y con su Comité Local de Refugiados. Los últimos en evacuar serían el grupo de voluntarios de la localidad, junto con los funcionarios del Ministerio y las autoridades militares. Mírese la orden del Ministerio de Sanidad y Asistencia Social en GR, n 86, 27-3-37, pág. 1.390.

12 Salvo nota en contrario, los datos demográficos sobre los desplazados de los pueblos del norte de Toledo proceden de varias fuentes principales. En primer lugar, de los testimonios recogidos por los informantes para La Causa General. Generalmente, son números de ausentes referidos al momento de la ocupación y derivan de la declaración tomada por el comandante del puesto de la Guardia Civil, llevada a cabo en 1942. Salvo el supuesto de Navalcán están tomados del Archivo Histórico Nacional-Madrid (AHN-M). FC-Causa General. Caja 1049/1, pza. 2a , pueblos respectivos. En segundo lugar, del reportaje publicado por Santos Martín de Diego en la revista Horizontes. El artículo supone un recorrido por los pueblos de la provincia de Toledo situados al norte del río Tajo y se basa en la transcripción literal o indirecta de una serie de entrevistas realizadas a los alcaldes y secretarios. Las preguntas versaban sobre la «historia», «el tránsito por la dominación roja», «el relato de la actuación de los rojos», así como por la actualidad del pueblo. Sobre ello véase: DE DIEGO, S. M., «Toledo y su provincia en los destinos de España», Horizontes: revista gráfica y literaria. Pasajes (Santander), Artes Gráficas, n 1, enero de 1938, pueblos respectivos. Para calcular los porcentajes de desplazados de los pueblos hemos utilizado, como norma, los datos de población de hecho de los municipios de Toledo en enero de 1936, que provienen de un estadillo confeccionado por las autoridades nacionalistas para determinar los maestros necesarios en la parte septentrional de la provincia, también utilizado en otros trabajos por José María Ruiz 
Calera y Chozas (3.955 habitantes de hecho, censo de 1930). El ejército de África ocupó Calera el día 2 de septiembre tras una tímida defensa preparada a las afueras del pueblo. De acuerdo con José María Ruiz Alonso, ${ }^{13}$ el alto porcentaje de mortandad de la posguerra - 48 items documentados- podría indicar que la localidad tuvo un desmesurado número de desplazados en el verano de 1936 y que la represión se cebó con una parte de los mismos a su regreso, ya en 1939.

Gamonal (1.778 habitantes de hecho, padrón municipal de enero de 1936). Según el primer edil de este municipio del partido de Talavera, Cándido Muñoz Valero, en declaraciones a Santos Martín de Diego para el especial de la revista Horizontes - de título «Toledo y su provincia en los destinos de España»-, los republicanos «se llevaron más de 570 habitantes» el 2 de septiembre de 1936, día de su «liberación» (más del 32,06\% de la población). ${ }^{14}$

Oropesa (3.691 habitantes en 1936). En este pueblo situado en la línea del avance principal de las tropas de Marruecos, que ofreció algunos focos de resistencia cuando fue ocupado por la Columna de Tella el día 30 de agosto de 1936, una gran parte de sus habitantes había huido con antelación. ${ }^{15}$ No disponemos de cifras concretas de desplazados, no obstante, Oropesa contaba con una población numéricamente considerable en 1936 que, con seguridad, se vio afectada por los acontecimientos vividos las jornadas precedentes.

Talavera de la Reina (14.876 habitantes de acuerdo con el censo de población de 1930). Talavera, importante ciudad castellana ubicada en el avance principal del ejército de África, entre la convergencia de los ríos Tajo y Alberche, quedó reducida después de la «liberación» del 3 de septiembre a 5.000 personas, eso sin contar una población militar superior a los 2.000 soldados (Heraldo de Aragón, 24 de septiembre de 1936). Si tomamos la cifra de 5.000 habitantes como correcta, Talavera perdió como mínimo el $66,38 \%$ de sus vecinos tras la «conquista». El día 4 de septiembre los titulares del Heraldo de Aragón reflejaban ampliamente la toma de Talavera de la Reina, referente de vital importancia como punto de confluencia de importantes carreteras de comunicación de Toledo, Madrid y Ávila. Conforme al

\footnotetext{
Alonso. RUIZ ALONSO, J. M., La guerra civil en la provincia de Toledo. Utopía, conflicto y poder en el sur del Tajo (1936-1939). Ciudad Real, Biblioteca Añil, 2004, tomo II: pp. 351-352. Mediante el estadillo disponemos de los guarismos de la población de hecho de 86 de las 116 localidades ocupadas del norte provincial para 1936 (padrón de enero de 1936). Como faltan los datos de algunos pueblos nos vimos obligados a utilizar el Censo de 1930. En este sentido: Archivo Histórico Provincial de Toledo (AHPTO). Fondos del Instituto. «Datos estadísticos sobre la enseñanza primaria en la provincia de Toledo», 883/8, Salida $n^{\circ} 255$, Estadillo $n^{\circ} 6$ ó Instituto Nacional de Estadística, Censo de 1930, Toledo (http://www.ine.es/jaxiBD/tabla.do, 15-7-08).

${ }_{13}$ RUIZ ALONSO, J. M., «Nuevos datos sobre la represión franquista en la provincia de Toledo» en ALÍA, F., y DEL VALLE, A. R., (Coord.): La Guerra Civil en Castilla-La Mancha. 70 años después. Cuenca, Ediciones de la Universidad de Castilla-La Mancha, 2008, pp. 1.531-1.559.

${ }^{14}$ Somos concientes de que los cálculos de Gamonal y de otras localidades están infravalorados porque, según el texto, se fueron «más de 570 habitantes» y hemos realizado nuestras operaciones teniendo en cuenta sólo 570 vecinos.

15 RUIZ ALONSO, J. M., «Nuevos datos...», pág. 1.536.
} 
testimonio de un huertano evadido, recogido por el corresponsal del diario Ahora, cuando los rebeldes se dieron cuenta de que la población se marchaba campo a través en dirección a La Calera, Oropesa y La Calzada «a culatazos y tiros obligaron a regresar a Talavera a más de mil personas». La salida de miles de talaveranos en camiones, coches y trenes en dirección a Madrid fue totalmente espontánea. La evacuación no contó con la organización ni el requerimiento necesario de las autoridades republicanas, de ahí el caos que se vivió. En este sentido, en el noticiario norteamericano de tendencia neutral Hearsts Metrotone News, propiedad de William Randolph Hearst, quedaron para la posteridad imágenes inéditas en las que grupos de refugiados abandonaban Talavera antes de la llegada del ejército de África. ${ }^{16}$

Torralba de Oropesa (887 habitantes en enero de 1936). Torralba se ocupó el 30 de agosto de 1936, dos días después de la llegada del ejército de Marruecos a la provincia de Toledo. En el proceso judicial de La Causa General, con documentación destinada a la averiguación de los sucesos acaecidos durante la guerra civil así como la actuación de las autoridades e instituciones republicanas, los informantes ponían de relieve la fuga de «los elementos más destacados de izquierdas" ante la proximidad del ejército nacional. No obstante, el número de ausentes debió de ser poco numeroso porque el alcalde de este municipio del partido de Oropesa, al referirse en el cuestionario de Santos Martín de Diego a la actualidad del mismo, expresaba que venía realizando con normalidad los trabajos agrícolas y atendía todos los servicios.

Ventas de San Julián, Las (240 habitantes en 1936). Antes del inicio del conflicto Las Ventas tenía prácticamente la misma población que una vez ocupado por las tropas marroquíes. Entendemos, por tanto, que este municipio más alejado de las principales comunicaciones de la provincia, en el que no ocurrió nada digno de mención las semanas previas, tampoco resultó muy afectado por las migraciones provocadas por la guerra. Así lo manifestaba Antonio Amor, alcalde del pueblo, en el especial de la revista Horizontes: «(...) doscientos cincuenta habitantes formamos actualmente en agrupación esta pequeña vecindad en la que todos [vivimos] felices y sin problemas».

16 Para esta ciudad hemos consultado en prensa: Heraldo de Aragón, n 14.380, 4-9-36, pág. 5; n 14.397, 24-9-36, pág. 6 y Ahora, n 1.787, 16-9-36, pág. 5. Léase también DíAZ, B., «Sobrevivir en tiempos difíciles: vida cotidiana y cultura popular en Castilla-La Mancha» en ALÍA, F., y DEL VALLE, A. R., (Coord.): La Guerra Civil en Castilla-La Mancha. 70 años después. Cuenca, Ediciones de la Universidad de Castilla-La Mancha, 2008, pp. 673-723. Véase igualmente el informativo Hearst Metrotone News: «Defense by Government troops of Toledo, Spain» ( 25 de septiembre de 1936, Hearst Metrotone News, Inc). Ucla Film and Television Archive. La referencia de este material no utilizado esta tomada de: AMO del, A. (Ed.), Catálogo general del cine de la guerra civil. Madrid, Cátedra/Filmoteca Española, 1996, pág. 530. 


\section{LOS EVACUADOS DE LOS PUEBLOS DEL SECTOR TALAVERA-SANTA OLALLA}

La caída de Talavera de la Reina tuvo consecuencias políticas inmediatas y el impacto provocado, con más de 500 muertos y miles de prisioneros, llevó a los responsables militares a replantearse la estrategia, de ahí la importancia que dieron en esta fase de la guerra a la defensa del eje Cazalegas-Maqueda. Ante el desastre, el republicano Asensio Torrado era ascendido a general y sustituía como jefe del teatro de operaciones de la zona Centro al general Riquelme. La misión no era otra que ordenar el frente del Tajo. Asensio era un firme partidario de la ofensiva, política militar que simultanearía con las fortificaciones y tácticas defensivas promovidas por el Estado Mayor. El objetivo principal del nuevo mando militar se centró en recuperar Talavera y para ello las fuerzas republicanas se reforzaron con tropas de la sierra, de Valencia, de La Mancha, de Murcia y de Cataluña, aunque, después de varias intentonas el 5 y el 8 de septiembre, fracasó. ${ }^{17}$

A pesar de la coyuntura, los rotativos republicanos intentaban transmitir esos primeros días de septiembre un clima favorable a la política militar del gobierno y dedicaron páginas principales a la teórica vuelta de los campesinos extremeños y toledanos a sus pueblos, una vez «reconquistados» por el ejército de la República. Así, la versión madrileña de $A B C$ reivindicaba el nuevo empuje en ese frente hasta el punto de que los que abandonaron sus lares volvían en caravana a los mismos. Se observaba, por ello, mucha animación ante el regreso de las familias que habían huido de sus casas por temor a los bombardeos. En esta misma órbita, de acuerdo con la crónica publicada por el redactor José Quílez del periódico Ahora, el éxodo de cientos de familias por veredas, hatajos y caminos ante la llegada de los de África se convertía ahora en bandadas de campesinos de vuelta a casa. Otros periódicos de mayor calado ideológico como Claridad, portavoz del sindicato UGT, destacaban el origen social de estos desplazados del frente de Talavera como gentes sin casa propia, pertenecientes a las capas más desfavorecidas de la sociedad. ${ }^{18}$

Con Talavera como base de operaciones contra la capital, la «Columna Madrid» mantuvo la línea norte del río Tajo por la carretera principal de Extremadura hacia Santa Olalla y Maqueda, haciendo también incursiones por otras vías de comunicación. La pretensión era, senlazar con el ejército del Norte. Sin embargo, la primera línea de protección republicana colocada en Cazalegas, con alambradas y trincheras hasta el río Tajo, impidió a los nacionales controlar este pueblo hasta pasados dos días - 11 y 12 de septiembre_, con más de 120 bajas.

17 Léanse CARDONA, G., Op. Cit., pp. 78-79 y SALAS LARRAZÁBAL, R., Op. Cit., pp. 262-263 y 469.

18 Véase por parte republicana: $A B C$ (Madrid), no 10.382, 6-9-36, pp. 11-12 y n 10.383, 8-9-36, pág. 4; Ahora, n 1.781, 9-9-36, pp. 8-9, n 1784, 12-9-36, pág. 8. Mírese también el artículo de llsa Wolf publicado en Claridad, $\mathrm{n}^{\circ} 139,14-9-36$, pp. 4-5. 
La «Columna Castejón» ocupaba el día 11 Navamorcuende e Hinojosa de San Vicente y, el día 12, Almendral, El Real de San Vicente y Pelahustán. ${ }^{19}$

A pesar del secretismo, las revelaciones de la progresión por el sector de Talavera-Santa Olalla irrumpían en zona republicana como un reguero de pólvora. Primero, las noticias de que los «fascistas» entraban el día 12 en Cazalegas, después que enfilaban rumbo hacia El Casar de Escalona. Leocadio Moreno, con doce años en 1936, cuenta que llegaban rumores a El Casar de que los moros no respetaban nada: — «Que vienen matando, vienen robando y vienen..., decían». ${ }^{20} \mathrm{El}$ pueblo fue tomado provisionalmente el día 15 de septiembre tras fuertes combates en los que la Columna de Castejón sufrió numerosas bajas no cuantificadas. El veterinario, que huyó el día 16, recaló en Santa Olalla. Sus testimonios sobre el asesinato de 11 casareños fueron definitivos para la despoblación que encontraron los nacionales al entrar posteriormente en esta villa de la carretera de Extremadura.

La prensa republicana, independiente o de empresa, no reflejó la "conquista» de estos lugares pero, como vemos, la información de los hechos llegaba a través de los propios desplazados. Solamente Milicia popular, el diario del $5^{\circ}$ Regimiento, además de mostrar su propósito de reclutar otros 10.000 milicianos más para reforzar la zona Centro, constataba lo doloroso que era contemplar esas caravanas de familias que abandonaban los pueblos. ${ }^{21}$

Pero los de Franco seguían su marcha hacia Santa Olalla. El día 17 de septiembre, en un profundo avance, alcanzaron la línea El Casar de Escalona-El Bravo-Los Cerralbos-Illán de Vacas. Finalmente, las tropas al mando del general Asensio Torrado no pudieron contener el empuje y Santa Olalla fue tomada el día 20. ${ }^{21 b i s}$ Para la invasión de Maqueda — defendida por el general republicano Carlos Masquelet- se siguió la carretera general y se ocupó el 21 de septiembre tras una importante resistencia miliciana por el único sitio no fortificado. ${ }^{22}$

19 Archivo General Militar de Ávila (AGMA). Documentación Nacional (DN). Operaciones sobre Madrid (OM): «Ordenes de Operaciones (Ejército Expedicionario)», Cáceres, 10 y 11 de septiembre 1936. Legajo 2/21.2, pp. 1-2 y 7; y «Avance Nacional de Talavera a Maqueda del 3 al 21 (Varias Columnas)». Legajo 2/18. Resulta ilustrativo el relato presentado en MARTíNEZ BANDE, J. M., La marcha sobre Madrid. Servicio Histórico Militar. Madrid, San Martín, n 1, 1982, pág. 176. Véanse igualmente los partes de guerra de los días 11, 12 y 13-9-36: Ejército Nacional, pp. 37-38 y Ejército de la República, pp. 47-50. Para una información más amplia sobre las operaciones en la comarca consúltese: COLLADO, J. C., La guerra civil en el Casar de Escalona. Del paseo militar a la resistencia planificada (1936). Toledo, Azacanes, 2008, pp. 51-52

20 Entrevista realizada a Leocadio Moreno Santana el 18 de octubre de 2008 en Madrid.

21 Véase en prensa: Heraldo de Madrid, n 15.768, edición de la noche, 15-9-36, pág. 2. El Sol, 159-36, pág. 3; 16-9-36, portada. El Liberal, 16-9-36, pág. 3 y un periódico de guerra como Milicia popular, n० $45,16-9-36$, pp. 3 y 5.

21bis AGMA. DNOM: «Avance Nacional de Talavera a Maqueda del 3 al 21 (Varias columnas)». Legajo 2/18. Utilizamos asimismo como fuente secundaria MARTINEZ BANDE, J. M., Op. Cit., pp. 176-177. Revísense para este punto los partes de guerra desde el día 17 hasta el 20-9-36: Ejército Nacional, pp. 39-40 y Ejército de la República, pp. 53-57. Sobre todo ello léase también COLLADO, J. C., Op. Cit., pp. 59 y 63.

22 A estos efectos se puede consultar: AGMA. DNOM: «Orden de operaciones en Talavera», 21 de septiembre de 1936. Legajo 2/20; y los partes de guerra de esos días: Ejército Nacional, pág. 41 y Ejér- 
En La forja de un rebelde, de Arturo Barea, ${ }^{23}$ quedó constancia de las evacuaciones de los pueblos localizados entre Talavera y Santa Olalla. La oleada de población civil transitando por la carretera de Extremadura en torno al 20 de septiembre, mezclada en ocasiones con desertores milicianos, aparecía reflejada en su obra de esta manera:

«Fausto guiaba a toda velocidad. Comenzamos a pasar milicianos sentados en la cuneta, descalzos, las botas o las alpargatas al lado de los pies desnudos (...) Por último, la carretera se convirtió en una masa humana. Milicianos cojeando, mezclados con campesinos que marchaban llevando del ronzal la mula o el burro en el que iban la mujer y los chicos (...) Así llegamos a Navalcarnero».

En periódicos nacionales, como Heraldo de Aragón, se dedicó un gran despliegue informativo a la toma de Santa Olalla y, sobre todo, de Maqueda. $A B C$ de Sevilla ponía la atención, como sus homólogos republicanos aunque por distintas causas, en el confiado regreso a sus casas de los campesinos toledanos una vez afianzadas las posiciones del ejército nacional en los pueblos del sector de Talavera (Cazalegas, El Casar de Escalona, Santa Olalla y Maqueda). Mientras tanto, en un diario republicano de empresa como $L a$ Voz, el corresponsal en el frente del Tajo denunciaba el fenómeno ya cotidiano de las caravanas de campesinos en éxodo de sus pueblos al aproximarse las fuerzas sublevadas. Los noticiarios de la British Movietone News, los primeros en introducir el sonido en las salas del Reino Unido, trataron la guerra de España desde una óptica teóricamente neutral. En la edición centrada en los combates del valle del Tajo se informaba que los nacionalistas habían reducido a ruinas la localidad de Santa Olalla. El propio cámara de Moviotone ayudaba a una familia de evacuados a volver a un lugar seguro. ${ }^{24}$ Fueron miles los toledanos que huyeron de sus pueblos entre el 3 y el 21 de septiembre de $1936 .{ }^{25}$

Alcabón (1.500 personas en 1936 conforme a los informantes de La Causa). La villa fue tomada por los nacionales el 21 de septiembre de 1936 y, según La Causa General, esa fecha se contabilizó una población de unos 650 habitantes «siendo antes del Movimiento el censo de 1500». Es decir, escapó más de la mitad de la población de Alcabón (el 56,67\%).

cito de la República, pp. 58-60. Igualmente, resulta interesante la descripción presentada en MARTíNEZ BANDE, J. M., Op. Cit., pp. 177-178.

${ }^{23}$ Arturo Barea redactó entre 1939 y 1941 los tres volúmenes de su libro. Consúltese BAREA, A., La forja de un rebelde. Barcelona, Debate, 2000, pág. 671.

24 Examínese por parte nacional: Heraldo de Aragón, no 14.395, 22-9-36, pp. 4-5. ABC (Sevilla), n 10.394, 22-9-36, portada; $n^{\circ} 10.396,24-9-36$, pág. 5. Por el lado republicano: La Voz, 26-9-36, portada; y Heraldo de Madrid, $\mathrm{n}^{\circ} 15.773,21-9-36$, portada y $\mathrm{n}^{\circ} 15.774,22-9-36$, portada. Por último: British Movietone News (24 de septiembre de 1936, British Movietone News). British Movietone Film Library. BM. Vol. $8 \mathrm{~N}^{\circ} 381 \mathrm{~A}$. La referencia del noticiario procede de: AMO, A. del (Ed.), Op. Cit., pág. 180.

25 Los cálculos numéricos del éxodo poblacional de las localidades ganadas a la República en el eje Cazalegas-Maqueda proceden igualmente, salvo nota específica, de varias fuentes principales: AHN-M. FC-Causa General. Caja 1049/1, pza. 2a, pueblos respectivos; DE DIEGO, S. M., Op. Cit., pueblos respectivos. Los datos padronales y censales constan en AHPTO. 883/8, Salida $n^{\circ} 255$, Estadillo $n^{\circ} 6$ ó INE, Censo de 1930, Op. Cit. 


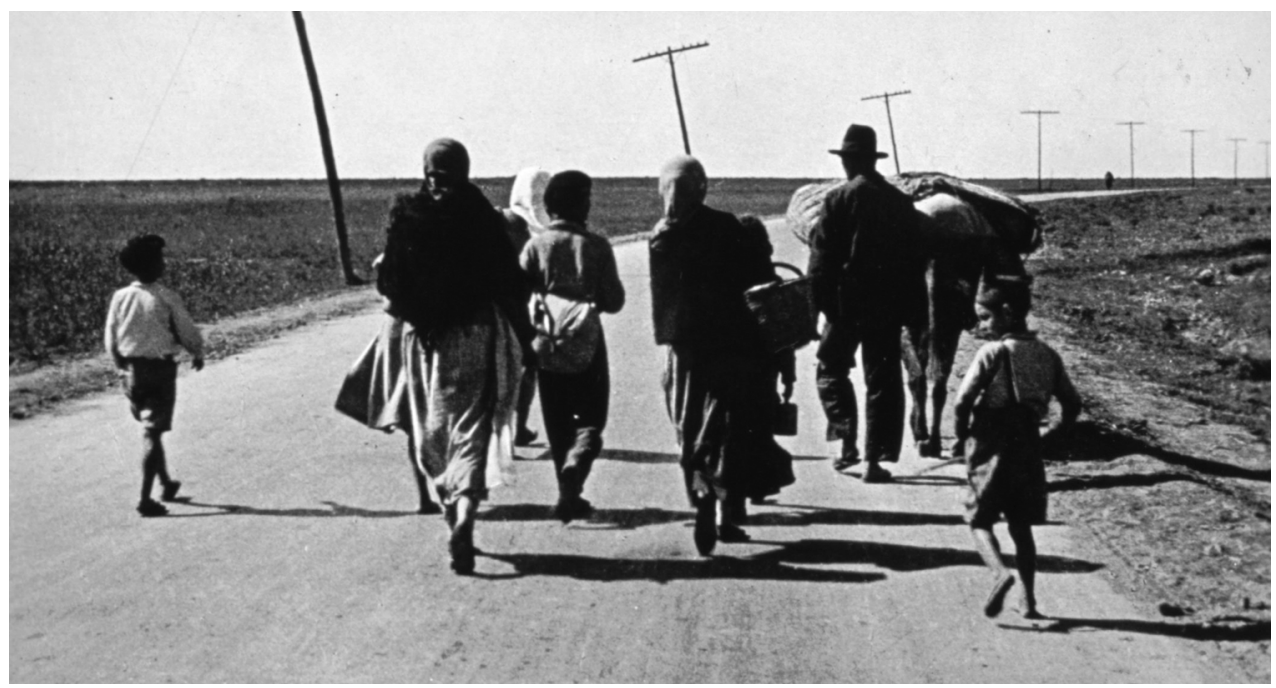

Foto N. ${ }^{\circ}$ 2. Biblioteca Nacional. Guerra Civil. Caja N. ${ }^{\circ} 42$, Varios frentes.

Carriches (921 habitantes en 1936). Según el reportaje elaborado para el magacín Horizontes, esta pequeña localidad del partido de Torrijos, dirigida por Vicente Sánchez Velarde, había sufrido «graves quebrantos durante el dominio rojo», motivo por el que tenía 400 huidos (el 43\% de los vecinos de Carriches).

Casar de Escalona, El (1.956 habitantes en 1936). Este municipio del antiguo partido de Escalona se ocupó definitivamente el 17 de septiembre de 1936. Según Leocadio Moreno, algunas familias se marcharon el mismo día 15 al comenzar las escaramuzas «por los tiros y el miedo a la atrocidad». Por las Actas Municipales sabemos que en octubre del mismo año todavía se ausentaban «cerca o más de cien familias completas» (en torno a 600 personas, alrededor del 30,67\% de la población). Teniendo en cuenta que cada familia estaba compuesta, como mínimo, por una media de entre 5 y 6 miembros, el dato aportado por el segundo alcalde de la «era azul», Justo Acuña Arroyo, a la revista Horizontes, en referencia a que 590 vecinos abandonaron el municipio —el 30,16\% de la población según esta fuenteno debería de estar muy alejado de la realidad. La huida principal del 16 de septiembre fue bastante superior pero, pasados unos días, el número de desplazados se estabilizó en una cifra cercana a las 600 personas. Irineo Sabrido, con cinco años en 1936, todavía recuerda ese momento: «Los que nos quedamos por aquí cerca volvimos, pero seguramente que más de medio pueblo se fue ese día. Los que se fueron a Madrid, ésos no volvieron». ${ }^{26}$

26 Véase: Archivo Municipal El Casar de Escalona (AMECE). Libro de Actas del Ayuntamiento de El Casar de Escalona ( $L A A E C E$ ), sesión del 14-10-36, pág. 62. Las familias desplazadas no se componían solamente de la clásica familia nuclear de padres e hijos, a éstos podían acompañarles hermanos, tíos 
Erustes (558 habitantes en 1936). Si nos ceñimos al reportaje de Santos de Diego, en este pueblo, dirigido en la Alcaldía por Alejandro Sánchez, las izquierdas, muy poco votadas en las últimas elecciones, se llevaron más de 280 habitantes en su huida «para hacerles morir de hambre en las calles de Madrid» (al menos el $50,18 \%$ de la población).

Maqueda (840 habitantes en 1936 según La Causa Genera). Gracias al testimonio de los informantes de La Causa sabemos que Maqueda, municipio estratégico del partido de Torrijos que había sido fortificado y presentó un importante foco de resistencia a las fuerzas nacionales, fue uno de los lugares de Toledo con mayor número de desplazados en proporción a su vecindario: «El censo de población antes del Movimiento era de 840 habitantes quedando unos 30 a su liberación». Por tanto, acorde con esta fuente, el día 21 de septiembre de 1936, fecha de la ocupación, se encontraban en el pueblo escasamente unas 30 personas, el resto —el 96,43\% — había iniciado ya su éxodo.

Navalcán (3.641 habitantes en 1936). Ajustado a La Causa, al llegar las tropas del comandante Del Oro a la localidad de Navalcán, ocupada efectivamente el 5 de septiembre, se ausentaban 120 personas huidas a la «zona roja» (el 3,29\% de la población). El hecho de encontrarse alejado de las principales vías de combate, en el ala izquierda del avance, favoreció que los habitantes de este pueblo permanecieran en sus hogares. ${ }^{27}$

Pelahustán (1.491 personas en 1936). En palabras del regidor de este municipio del partido de Escalona en 1936, Jesús Amigo González, faltaban «más de 260 habitantes» (el 17,44\%). Pelahustán fue ocupado por primera vez el 12 de septiembre de 1936 por la «Columna Castejón» pero, ante el empuje de las fuerzas del gobierno y la resistencia local, volvió a pasar a territorio leal hasta que el 12 de octubre quedó definitivamente en el lado nacional.

Real de San Vicente, El (2.140 habitantes en 1936). El alcalde de esta localidad del partido de Talavera, Andrés Arias Díaz, en respuesta al cuestionario elaborado para Horizontes ofrecía el dato de que se ausentaban del pueblo 97 habitantes (el 4,53\%). El Real se ocupó sin resistencia en un avance secundario de la «Columna Castejón» el 12 de septiembre de 1936 pero muchos residentes habían huido ya con sus enseres y ganado. En cualquier caso, presumimos que el número

\footnotetext{
y abuelos de cualquiera de los cónyuges $u$ otros parientes por afinidad o consanguinidad. A modo de ejemplo, desde Madrid evacuaron a la localidad de EI Romeral 75 personas procedentes de 14 familias de El Casar, a una media de 5,36 miembros. No obstante, nosotros tomaremos como referencia 5 individuos por familia salvo en los supuestos, como precisamente el de El Casar de Escalona, en los que el texto refiere que se ausentaron más familias de las 100 que vamos a contemplar: «más de cien familias completas». En casos como éste utilizaremos un coeficiente de 6 para no distorsionar demasiado, por defecto, los resultados. Los testimonios están tomados de las entrevistas realizadas a Leocadio Moreno Santana e Irineo Sabrido Rico, el 18 de octubre y el 15 de noviembre de 2008, en Madrid y El Casar de Escalona respectivamente. Sobre los evacuados de El Casar léase COLLADO, J. C., Op. Cit., pp. 105108.
}

${ }^{27}$ AHN-M. FC-Causa General. Caja 1045/1, pza. 1a, Navalcán. 
total de desplazados pudo ser superior y esto explicaría, en parte, la alta edad media de los asesinados durante el «primer terror» o represión en caliente ejercida por el ejército franquista. ${ }^{28}$

Santa Olalla (3.078 habitantes en 1936 ajustado a La Causa). Aunque el más importante núcleo defensivo republicano se situó en Maqueda, el dispositivo de Santa Olalla fue también considerable. En sus llanuras se libraron fuertes combates que terminaron con las milicias en retirada. De acuerdo con el proceso de $\mathrm{La}$ Causa, en esta villa «liberada» el 20 de septiembre, estratégicamente situada en la carretera de Extremadura, quedó escasamente «un Censo de población de unos 400 habitantes, siendo antes del Movimiento Nacional de 3.078». Es decir, el éxodo preliminar afectó nada menos que al $87 \%$ de una población atemorizada por las noticias que llegaban de los pueblos ocupados en las jornadas precedentes. En la misma línea apuntaba el registro del alcalde cuando afirmaba que Santa Olalla era una villa que presentaba una estampa triste por la ausencia "de más de 2.600 » habitantes. La falta del $87,30 \%$ del vecindario, según el primer edil, confirmaría la aseveración de los informantes para La Causa General.

\section{TOLEDO EN EL PUNTO DE MIRA}

Con la ocupación de Maqueda asomaba expedito el camino hacia la capital de España, pero una decisión histórica llevó a Franco a desviarse hacia Toledo para liberar el Alcázar. Los 75 kilómetros de distancia entre Maqueda y Madrid pasaban a ser 111 con la modificación de la ruta. ${ }^{29}$ El general Franco relevó a Yagüe -contrario al desvío- por Varela, con el apoyo de Asensio y Barrón. El cambio, efectivo el día 22 en Maqueda, parece íntimamente relacionado con la decisión de encaminarse hacia la ciudad imperial.

Por unos días, la mayor avalancha de caravanas de carros campesinos dejaba la carretera de Extremadura y enfilaba por los caminos de Toledo. Después de Maqueda, las tropas republicanas se dividían en dos facciones, una al mando de Burillo para cubrir el flanco de Toledo, y otra dirigida por el coronel Sánchez Plaza con la misión de defender el avance hacia la capital de España. Pero las medidas del gobierno no fueron efectivas. Desde Santa Olalla los nacionales acometieron la ocupación de Val de Santo Domingo, hecho consumado por Asensio el día 22. Por otra parte, en una acción conjunta de Castejón, marchando desde Alcabón con Asensio por el norte, Torrijos cayó también el mismo 22 de septiembre, y así aparecía documentado en la prensa afín al levantamiento con graves críticas hacia

28 Mírese RUIZ ALONSO, J. M., «Nuevos datos...», pág. 1.539.

29 Las operaciones militares de estas jornadas aparecen detalladas en MARTíNEZ BANDE, J. M., Op. Cit., pp. 176-178 y 181. Sobre la polémica del desvío hacia El Alcázar léase un interesante artículo de VALERO RAMOS, R., "25 días que cambiaron la guerra» en La Guerra Civil española mes a mes. Madrid, Unidad Editorial, tomo 5, 2005, pp. 7-11. 
el militar republicano Asensio Torrado. Por supuesto, los partes de guerra del ejército nacional insistían en estas importantes victorias y a partir del 25 de septiembre se centraban en el avance de las columnas hacia Toledo. ${ }^{30}$

El noticiario británico Gaumont British News, neutral en consonancia con la política de «No-Intervención» adoptada por el Reino Unido, dedicó también una edición a Toledo y a los pueblos cercanos. A una serie de instantáneas en las que apreciamos Toledo, las ruinas del Alcázar, el Zocodover y otros puntos, así como la visita del presidente del gobierno, Francisco Largo Caballero, a las ruinas de la ciudad, se sucedían otras de civiles caminando, huyendo del itinerario de las tropas nacionales. También podemos ver a las fuerzas de Franco avanzando hacia Toledo. En la misma línea, el informativo norteamericano Fox Movietone News, uno de los de mayor importación y difusión, editaba en septiembre el noticiario «Francisco Largo Caballero visita Toledo» con especial atención al paso del ejército de África por la provincia de Toledo y a los campesinos huyendo de los combates. ${ }^{31}$

Finalmente, en la jornada del 27 de septiembre de 1936 las fuerzas nacionalistas irrumpían en Toledo. Según el informe «Evacuación de Toledo», firmado por Burillo el 30 de septiembre, a las cinco de la tarde del día 27 la defensa de la capital del Tajo era ya a la desesperada. De esta suerte, a las seis tuvo que ordenar la evacuación de la ciudad. Mientras salían por el puente de San Martín «el enemigo" entraba por la puerta de Bisagra. Cuando esa tarde los marroquíes accedían a Toledo ya se habían retirado las fuerzas republicanas y la artillería. Por ello, los moros y la Legión solamente encontraron una tenue resistencia militar por parte de algunos voluntarios de las milicias toledanas, que acabaron muriendo combatiendo o fusilados. ${ }^{32}$

Desde el 3 de septiembre, fecha de la caída de Talavera de la Reina, hasta el día 28, con la entrega definitiva de Toledo, transcurrieron veinticinco días. Conforme a los hechos analizados, las columnas africanas fueron encontrando una mayor oposición según se acercaban a Madrid, a pesar de una superioridad manifiesta en medios de guerra. Pero la ocupación de Santa Olalla, Maqueda y Torrijos en tres días fue un golpe muy duro para el gobierno de la República que no solamente provocó la desbandada de la población civil sino también numerosas deserciones de milicianos. La razia inicial tras la conquista de los pueblos entre Talavera y Maqueda se transmitía de forma oral a las localidades de la ruta, provo-

30 Véase SALAS LARRÁZABAL, R., Op. Cit., pág. 484 y los partes de guerra de los días 22 al 27 de septiembre de 1936: Ejército Nacional, pp. 41-43; también por lo que hace a la prensa puede verse: $A B C$ (Sevilla), n 10.395, 23-9-36, portada y pág. 6.

31 Gaumont British News: «Spain from both sides, Front-line despatches from Government and Rebel» (28 de septiembre de 1936, Gaumont British Picture Corporation). Filmoteca Española. GB.287. Y Fox Movietone News: «Francisco Largo Caballero visita Toledo» (septiembre de 1936, Movietonews Inc.). Bundesarchiv-Filmarchiv de Berlín. Consúltense las reseñas de los informativos aludidos en AMO, A. del (Ed.), Op. Cit., pp. 491 y 442.

32 SALAS LARRAZÁBAL, R., Op. Cit., pp. 486-487. 
cando no solamente la evacuación de la población afín a la República sino igualmente la de miles de campesinos que, independientemente de ideologías, huían por miedo a las bombas y a la guerra. ${ }^{33}$

Carmena (2.070 habitantes en 1936). En Carmena, de acuerdo nuevamente con los informantes de La Causa llevada a cabo por el franquismo, el 26 de septiembre de 1936, fecha de la ocupación, había escapado el $40 \%$ de la población «en su mayoría extremistas y personas temerosas de la acción de la justicia por su actuación durante la dominación roja». La localidad contaba en 1936 con 2.070 habitantes y, según el porcentaje presentado en dicha fuente, el éxodo afectó a más de 800 oriundos del municipio.

Escalonilla (3.702 habitantes en 1936). Merced al informe de La Causa, y por los mismos motivos que en Carmena, a la llegada de las fuerzas nacionales el 22 de septiembre de 1936 había huido el 20\% de la población. Cifra similar de ausentes ofrecía su alcalde, Valentín Querencia Merino, en el reportaje publicado sobre Escalonilla en la revista Horizontes (600 personas evacuadas, un porcentaje superior al $19,53 \%$ del vecindario).

Gerindote (2.079 habitantes de hecho, censo de 1930). El alcalde de la localidad, Lucio Rodríguez Navarro, daba a entender en el cuestionario planteado por Santos Martín de Diego que «muchas familias» fueron arrastradas por los republicanos en su huida.

Novés (2.669 habitantes en 1930). En el libro de Arturo Barea se describieron también los momentos anteriores a la ocupación del pueblo («Novés estaba casi vacío»). Una vez en Madrid, ya en los primeros días de octubre, el molinero de Novés construía desde el principio el relato de la huida:

«Unos cuantos de los jóvenes se marcharon a Madrid con las milicias, pero la mayoría de nosotros nos quedamos y fuimos viviendo con lo poco de las huertas y lo que se había encontrado en las casas de los ricos. Cuando los rebeldes comenzaron a venir cerca, todos los otros pensaron que ellos no tenían nada que temer y se quedaron la mayoría. Unos pocos más se marcharon cuando cayeron las bombas que le conté, pero usted sabe qué apegado está uno a su casa y a la tierra de uno, y muchos se quedaron. Hasta que la gente de otros pueblos que venían huyendo pasaron por allí, y comenzaron a contar que los fascistas, cuando entraban en un pueblo, fusilaban a los hombres y cortaban el pelo al rape a las mujeres (...) Con una cosa y otra, al final, todos decidimos marcharnos, pero esto fue en el último momento, el día que usted pasó por allí. Cuando salimos, los fascistas estaban ya en Torrijos y en Maqueda y habían cortado la carretera a Madrid; así que nos tuvimos que meter a través de los campos. Nos cazaban como a conejos, y al que cogían le volaban los sesos; a las mujeres les hacían volver a culatazos al pueblo. Después, los moros vigilaban por los campos y cuando cogían

${ }^{33}$ Del mismo modo que en los apartados anteriores, salvo nota en contrario, los datos sobre los desplazados de los pueblos ocupados durante estas jornadas proceden de: AHN-M. FC-Causa General. Caja 1049/1, pza. 2a , pueblos respectivos; DE DIEGO, S. M., Op. Cit., pueblos respectivos y AHPTO. 883/8, Salida n²55, Estadillo n 6 ó INE, Censo de 1930, Op. Cit. 
una mujer que no fuera muy vieja la tumbaban en los surcos y ya puede usted imaginarse el resto». ${ }^{34}$

Puebla de Montalbán, La (7.593 habitantes en 1936). El proceso judicial de La Causa General únicamente testificó la ausencia de 250 personas al llegar los nacionales a este pueblo emplazado en la línea del avance principal, «la mayor parte de ellos por compartir igual ideales que los marxistas". Dato ciertamente dudoso que, en consonancia con la cifra de desplazados declarada por su alcalde Doroteo Morán López Hermoso («Faltan más de 1.700», al menos el 22,39\% de la población), estaría más cercano, por defecto, al número de familias fugadas. Como asegura Alfonso Martín Díaz-Guerra ${ }^{35}$ en el trabajo realizado sobre esta localidad del partido de Torrijos, cuando el 24 de septiembre de 1936 se ocupaba la villa, los dirigentes más destacados del Comité local, del Ayuntamiento y de la Casa del Pueblo habían escapado ya de la misma. Pero no fueron los únicos, de ahí los problemas para la recogida de las cosechas en las fincas abandonadas por los propietarios.

Quismondo (2.100 personas en 1936). De acuerdo con el testimonio del regidor del pueblo, Mariano del Castillo, los vecinos de Quismondo cuidaban con esmero "las casas de las 365 familias ausentes» para que a su regreso encontrasen una morada decente. Si tomamos como media 5 miembros por familia, estaban fugados más de 1.800 lugareños de este municipio de la carretera de Extremadura (el $86,90 \%$ del vecindario).

Normalmente escaseaban las noticias sobre los evacuados en los diarios nacionalistas pero el éxodo de Quismondo, por excepción, sí apareció documentado. De acuerdo con el periódico $A B C$, en su edición sevillana, el pueblo se hallaba «desierto» mientras los vecinos esperaban su ocupación para regresar a sus hogares. ${ }^{36}$

Toledo (27.443 habitantes de hecho, censo de 1930). El 27 de septiembre de 1936, al llegar los nacionales, se intentó evacuar a la población civil y a los heridos de Toledo. A este respecto, Isabelo Herreros destaca que, aunque todas las carreteras de salida estaban cortadas por los militares de África, el gobierno provincial del Frente Popular partió como pudo hacia Ocaña, vía Aranjuez, y una parte de la población, obreros del barrio de la Estación, en dirección a Madrid. En el sector sur de la ciudad un número importante de toledanos intentó cruzar el río Tajo, en barcas o a nado, ante el fuego cruzado de las tropas rebeldes. El resultado fue una balsa de cadáveres río abajo. ${ }^{37}$ Por tanto, a pesar de los intentos, la evacuación prácticamente no se pudo realizar. Revelaciones de supervivientes demostrarían que la huida fue un espectáculo tremendo, como la de un hombre, ya anciano, que

34 BAREA, A., Op. Cit., pp. 670 y 673-674.

35 MARTÍN DÍAZ-GUERRA, A., La Segunda República y la Guerra Civil en La Puebla de Montalbán (desde la perspectiva municipal). La Puebla de Montalbán (Toledo), El Autor, 2005, pp. 104 y 120-122.

${ }^{36} A B C$ (Sevilla), n 10.396, 24-9-36, pág. 5.

37 HERREROS, I., Mitología de la cruzada de Franco. El Alcázar de Toledo. Madrid, VOSA, 1995, pp. 71-73. 
vivió con su familia los días del asedio del Alcázar prácticamente encerrado en su casa. El viejo decidió escapar con su mujer y su hija, ante el doble fuego de los que sitiaban el Alcázar y de los que en él se defendían. Los disparos de ametralladora le dieron en la mano y alcanzaron a su esposa. El toledano explicaba así su drama: «Seguía el fuego. Corrí enloquecido. Mi mujer quedaba allí, muerta. Y de mi hija no he vuelto a saber más" (Mundo gráfico, 7 de octubre de 1936). El Jefe del Estado Mayor de las tropas republicanas de Toledo, en nombre del coronel Asensio Torrado, transmitía a las autoridades de Madrid, en una nota de despacho que no llegó nunca a su destino, las dificultades comentadas para llevar a cabo la evacuación de la ciudad. ${ }^{38}$

La madrugada del 27 de septiembre, una vez cargadas las piezas de artillería pesada en vagones de tren, el pintor Luis Quintanilla partía en coche desde Toledo hacia Madrid. De acuerdo con Quintanilla, aquellos días protagonista en el sitio del Alcázar, la evacuación de la población no pudo empezar hasta el día 30 y el espectáculo fue tan espeluznante que se prohibió a los periodistas y fotógrafos reproducir imágenes o transmitir información sin pasar por la censura. El propio artista evocaría posteriormente que aunque actuó directamente en el sitio del Alcázar: «(...) de todos mis dibujos ni en uno toqué aquel tema, a pesar de ser muy espectacular, pues teniéndole delante de los ojos no estaba en condiciones de verlo artísticamente». ${ }^{39}$

Cuando se acercaban las Columnas de Varela, el gobernador civil, José Vega, y el creado Consejo ampliado del Frente Popular, ordenaron asimismo la evacuación de todos los organismos y empleados de las instituciones. En los casos del Orfanato, del Asilo y del Hospital de Dementes, partieron además con la mayoría de los residentes (casi todos los huérfanos y asilados y 252 enfermos, en concreto, del Hospital de Dementes), y también emigraron más de 150 niños y varios profesores del Colegio provincial de Toledo, dependiente de la Diputación Provincial. De los aproximadamente 230 empleados de la Diputación y de sus entidades dependientes, 98 se quedaron y solicitaron su readmisión al Toledo nacional y 120 escaparon de la capital del Tajo. Incluso se desmanteló la Fábrica Nacional de cartuchería de Toledo y muchos técnicos y otros operarios se trasladaron con ella. ${ }^{40}$

Torrijos (4.121 habitantes en 1936). Aunque no disponemos de números precisos tenemos la certeza de que en Torrijos el éxodo resultó también bastante contundente. Según las declaraciones del primer edil faltaba «casi todo el pueblo» que había huido amedrentado «por la propaganda infame de los rojos». Surgían mul-

38 Revísese Mundo gráfico, no 1.301, 7-10-36. Véase la nota de despacho del Jefe del Estado Mayor de Toledo en ARRARÁS, J., Historia de la Cruzada Española. Madrid, Datafilms, 1984, vol. VI, pág. 39.

39 QUINTANILLA, L., «Pasatiempo». La vida de un pintor (Memorias). A Coruña, Edición do Castro, 2004, pp. 390 y 445. Mírese el pasaje de la llegada y ocupación de Toledo por las fuerzas nacionales en: QUINTANILLA, L., Los rehenes del Alcázar de Toledo. Paris, Ruedo Ibérico, 1967, pp. 204-207.

40 RUIZ ALONSO, J. M., La Guerra Civil..., II: pp. 352-353. 


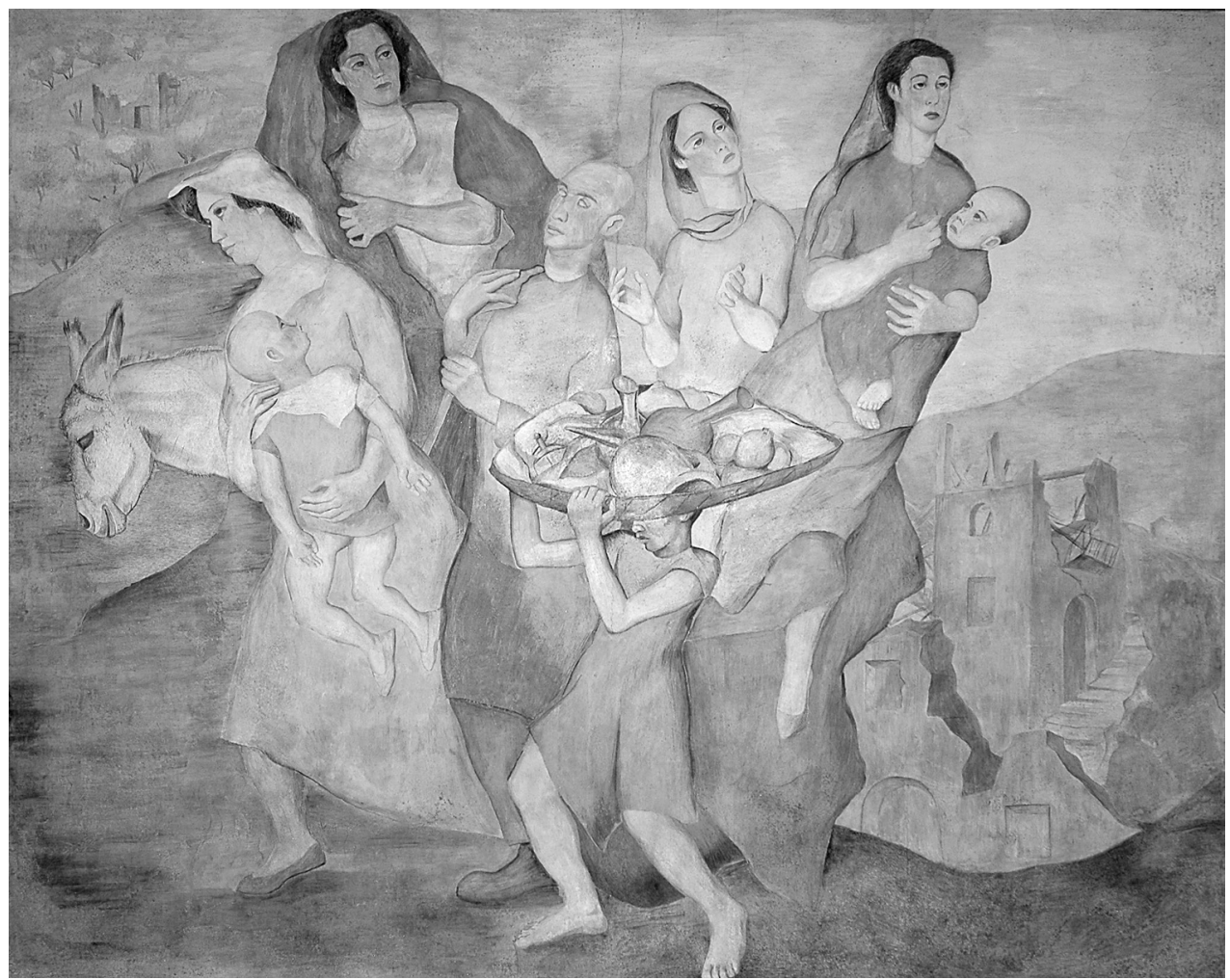

Documento N. 1 . La «Huida» del pintor Luis Quintanilla.

titud de inconvenientes en la localidad debido a que las casas abandonadas, por falta de atención, «se venían a tierra».

Nuevamente, en otro de sus viajes por las carreteras de Toledo, Arturo Barea era testigo de excepción de la riada de población que pretendía abandonar la villa, que daba ya nombre al partido judicial, ante la inminente llegada de los nacionales:

«En Torrijos, las calles estaban atascadas por carros y coches. Los habitantes estaban cargando en ellos ropas, colchones y muebles, dándose prisa unos a otros y gritando:

—QQué vienen los fascistas!».41

Jesús María Ruiz-Ayúcar cuenta también que, ante la violencia de los dos meses previos a la «liberación» del 23 de septiembre de 1936, muchos vecinos de

41 BAREA, A., Op. Cit., pág. 670. 
este pueblo huyeron donde tenían parientes o amigos ante el temor de ser detenidos o fusilados. A modo de anécdota, el 22 de septiembre se celebró en Torrijos, durante bastantes años, la fiesta del «Cristo de los Quedados» en honor a los que no quisieron marcharse en el «tren de la huida» y permanecieron hasta la ocupación. ${ }^{42}$

\section{EL ÉXODO DESPUES DE LA CAÍDA DE TOLEDO}

Durante todo el mes de octubre el éxodo de toledanos continuó. En general, en los pueblos de la carretera de Toledo habían quedado pocos habitantes. Algunos vecinos decidieron, a pesar de todo, permanecer en sus casas esperando la llegada de las tropas de Franco, unos por amor a sus hogares y alguno, como intuía el cronista de guerra Clemente Cimorra, porque «lo cierto es que está deseando la llegada del enemigo". ${ }^{43}$

Tras ser nombrado "generalísimo», Franco reorganizó las tropas nacionalistas en dos ejércitos: el del Norte, mandado por el general Mola con jurisdicción en el Centro, y el del Sur, a cargo del general Queipo de Llano. La misión de Mola era ocupar lo antes posible la capital de España y para ello disponía en el Centro de las tropas de Saliquet, divididas a su vez en dos sectores: el norte, denominado división o columnas de Ávila, al mando del general Valdés Cabanillas, y el sector sur, constituido por las agrupaciones africanas de Varela. Ambos ejércitos debían confluir en San Martín de Valdeiglesias. ${ }^{44}$ De esta manera, siguiendo el trayecto de la carretera de Toledo a Madrid, además de otros avances complementarios con el mismo destino y las operaciones desarrolladas en otros puntos tomando como base la carretera de Extremadura, la de Escalona o la que une la de Extremadura con Toledo, entre el 28 de septiembre y el 26 de octubre de 1936, los nacionales ganaron a la República el resto de localidades septentrionales. En este tránsito quedó marcado un día en el calendario nacionalista: el 6 de octubre, fecha de la «liberación» de los municipios de Portillo, Fuensalida, Huecas, Quismondo y Santa Cruz de Retamar. El resto de jornadas fueron cayendo, entre otros pueblos, EscaIona, Almorox, La Torre de Estebán Hambrán, Méntrida, Valmojado, Casarrubios, Olías del Rey, Cabañas, Villaluenga de La Sagra, Azaña, Pantoja, Juncos, Añover e Illescas, postrera población toledana en la carretera de Toledo a Madrid. Los nacionales tardaron tres semanas en cubrir los 37 kilómetros de distancia de Toledo a Illescas pero el camino hacia la capital de España parecía meteórico. Desde Illescas hasta Madrid había poco más de 30 kilómetros, de ahí los intentos republicanos las jornadas siguientes por recuperar la localidad. No habían fructificado las fortifica-

\footnotetext{
42 Para más información sobre Torrijos léase RUIZ-AYÚCAR ALONSO, J. M., Historia de Torrijos (de espacio rural a municipio urbano). Toledo, Diputación Provincial de Toledo, 2003, pp. 157-161.

${ }_{43}$ El periodista de guerra Clemente Cimorra, que finalmente recaló como exiliado en Argentina, trabajaba en 1936 para La Voz. La Voz, n 4.912, 6-10-36, portada.

44 SALAS LARRAZÁBAL, R., Op. Cit., pág. 518.
} 
ciones de la línea Escalona-Maqueda-Torrijos, ejecutadas por el general Masquelet, y todos los puntos de contención preparados fueron superados. El ejército de Mola ocupaba Esquivias el día 24 y Seseña el 25. Siguiendo la política republicana de contraofensivas, el último contraataque tuvo lugar el día 29 de octubre en el sector de Seseña-Esquivias pero, como había sucedido con Illescas, también acabó en fracaso. ${ }^{45}$ Según los datos de que disponemos hasta el momento parece ser que la razia disminuyó tras la toma de Toledo, lo que podría ser un indicio o bien de que las poblaciones que se iban encontrando los nacionales estaban prácticamente sin vecinos o bien de que las tropas tenían orden expresa de no practicar la violencia como hasta entonces.

En todo caso, durante octubre de 1936, con el ruido de las bombas de la aviación como telón de fondo, las evacuaciones del norte provincial continuaron llevándose a cabo de forma improvisada y desorganizada, más por el instinto vital de la población que por la actuación de las autoridades de la República (ya vimos los ejemplos espontáneos de ciudades tan importantes como Talavera y Toledo). El sistema de evacuación de las poblaciones, como adelantamos, no se estableció legalmente hasta marzo de 1937. Dos meses después de su entrada en la provincia de Toledo finalizaba la travesía del ejército de África en EI Viso de San Juan. A medida que avanzaba el frente de guerra aumentaba el número de pueblos despoblados en el camino hacia Madrid. ${ }^{46}$

Alameda de La Sagra (1.657 habitantes de hecho, censo de 1930). Valentín Pérez Alonso, primer edil de esta localidad situada entre la carretera de Toledo-Madrid y el río Tajo, manifestaba en la crónica impresa sobre la campaña militar de Franco por Toledo que faltaban del pueblo «unas cuarenta familias, los más rojos». Es decir, si tomamos el dato como correcto, y redondeamos en torno a 5 personas por familia, partieron de Alameda ante la llegada de las fuerzas nacionales unas 200 personas, el $12,07 \%$ de la población.

Almorox (3.011 habitantes en 1936). El pueblo fue «liberado» el 7 de octubre de 1936 tras los combates por la ocupación de Escalona y su antigua tierra. Su propio alcalde, Marcelino Escudero Rodríguez, declaraba la pérdida transitoria de 485 habitantes (el 16,11\% de los moradores), que habían convertido un pueblo animoso y activo, enclavado en un entramado de montañas, en una villa muerta.

Añover de Tajo (3.396 habitantes de hecho, censo de 1930). Con la toma de la ciudad de Toledo y el avance del ejército nacional por la línea del Tajo hubo una

45 La estrategia militar planteada después de la toma de Toledo aparece detallada en MARTíNEZ BANDE, J. M., Op. Cit., pp. 217-221 y 224-228. Véanse las operaciones desarrolladas en los últimos pueblos de Toledo en SALAS LARRAZÁBAL, R., Op. Cit., pág. 544.

46 La base de los datos obtenidos sobre el éxodo poblacional de las localidades perdidas por la República, desde la «conquista» de Toledo hasta la llegada del frente a las puertas de Madrid, proviene nuevamente, salvo nota específica, de varias fuentes principales: AHN-M. FC-Causa General. Caja 1049/1, pza. $2^{a}$, pueblos respectivos; DE DIEGO, S. M., Op. Cit., pueblos respectivos; y AHPTO, 883/8, Salida ${ }^{\circ}$ 255, Estadillo n 6 ó INE, Censo de 1930, Op. Cit. 


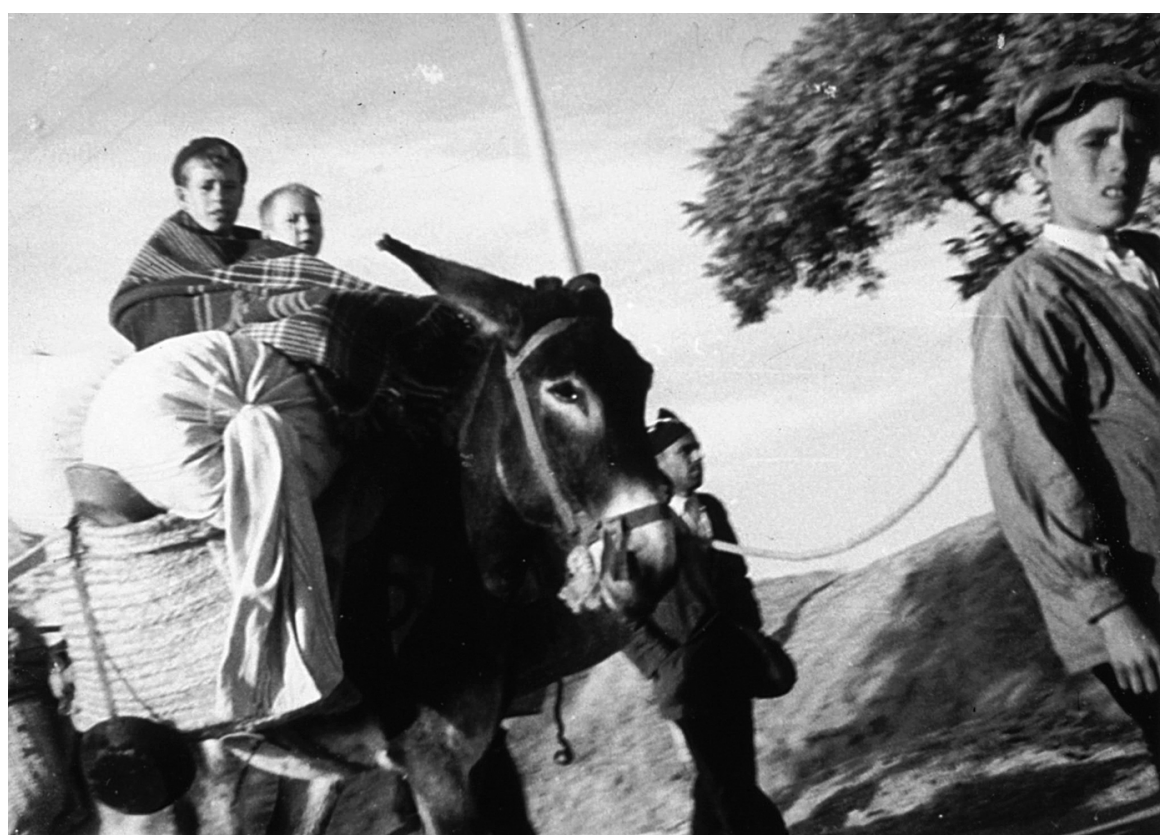

Foto N. 3. Biblioteca Nacional. Guerra Civil. Caja Azul. Madrid. Evacuaciones.

significativa concentración de tropas republicanas en Añover. Unos 15 días antes de la ocupación este hecho provocó un importante éxodo hacia otras zonas leales cercanas (Yepes, Villasequilla, Ocaña y Madrid). El resto se marchó el mismo domingo 8 de octubre, al ser tomado el municipio por las tropas de Franco. Según las estimaciones, Añover pasó de 3.890 vecinos en el quinquenio 1931-1935, a 1.296 en el periodo bélico, es decir, sufrió un descenso del $66,68 \%$ una vez asentada la población. ${ }^{47}$

Arcicóllar (793 habitantes de hecho, padrón municipal de enero de 1936). El informe para La Causa General, elaborado en 1942, destacaba que los primeros en entrar en el lugar el 19 de octubre de 1936 fueron las fuerzas de la Guardia Civil y los vecinos que durante «la dominación roja» escaparon a los pueblos cercanos. Conforme a la misma fuente sabemos también que los milicianos y paisanos de ideología izquierdista huyeron hacia Madrid antes de aproximarse las tropas nacionales. En cualquier caso, gracias a una colección de prensa como Horizontes, advertimos que Arcicóllar había quedado reducido a «la mitad de sus habitantes» (al menos el $50 \%$ de la población).

47 Para Añover hemos seguido: MAGÁN GARCíA, J. M. (Coord.), «Anover de Tajo: 1926/1949. Incidencia de la Guerra Civil en el desarrollo demográfico de una villa Sagrera en I/ Congreso Joven de Historia de Castilla-La Mancha. Madrid, Servicio de Publicaciones de la JCCM, 1988, pp. 107-108. 
Camarena (2.368 personas en 1936). De esta importante villa situada entre la carretera de Toledo a Madrid y el río Tajo, tomada por los nacionales sin apenas resistencia el 19 de octubre de 1936, quedó también breve constancia en La Causa de que «las milicias y los individuos de izquierda dos o tres días antes de la liberación huyeron hacia Madrid». Concretamente, este municipio del partido de Santa Cruz de Retamar, con Félix Elzaudiela y Lozoya al frente de la Alcaldía, "Contaba en la normalidad con más de dos mil habitantes pero la guerra marcó su garra negra arrancando más de la mitad».

Carpio del Tajo, El (4.245 habitantes en 1936). El alcalde de este pueblo del partido de Torrijos, Francisco Fernández Collado, declaraba para el reportaje «Toledo y su provincia en los destinos de España» la ausencia de 250 familias, a pesar de lo cual las labores del campo se realizaban con total regularidad. Si tenemos en cuenta que cada familia evacuada podía estar compuesta al menos por 5 miembros, de El Carpio estaba ausente más del 29,45\% de la población. Decir que la localidad fue ocupada por las tropas de Castejón el 29 de septiembre de 1936 sin ningún tipo de defensa documentada.

Cedillo del Condado (1.163 vecinos censados en 1936). Según el relato del alcalde, Julián Retana de Rojas, este pueblo situado en el trayecto de Toledo a Madrid y habitado antes de la guerra «por mil doscientos habitantes» ahora apenas si contaba con la mitad.

Cobeja (635 personas en 1936). Por revelaciones del primer edil de esta pequeña aldea del partido de Illescas, Severiano Orozco Calvo, estamos al corriente de que, «ante el terror infundido por los rojos», Cobeja tenía 200 habitantes huidos a la llegada de las tropas de Franco (el 31,50\% del vecindario).

Fuensalida (5.131 habitantes de hecho, padrón municipal de enero de 1936). De acuerdo con el alcalde de la villa, Marcos Rosino Martínez: «Faltan más de 2.600 habitantes, por lo que el pueblo tiene un aspecto triste y desolado». Según los números precedentes, Fuensalida perdió como mínimo la mitad de su población tras «la conquista» (más del 50,67\%).

Illescas (2.228 habitantes en 1936). Conforme apuntaba el primer edil de Illescas, Víctor Barroso Ugena, en esta importante localidad de La Sagra toledana junto a la carretera Madrid-Toledo desapareció el $80 \%$ del vecindario. Pocos días antes del 18 de octubre, fecha de la «liberación», la prensa informaba sobre el ya cotidiano desfile de caravanas de carros de evacuados que pasaban por Illescas, "medio vacío ya». ${ }^{48}$

Olías del Rey (1.356 habitantes de hecho, censo de 1930). En este municipio situado en la carretera Toledo-Madrid, a pocos kilómetros de la capital provincial, según respuesta de su alcalde nacional, Maximiliano de Lucas, faltaban «más de

48 IZCARAY, J., La guerra que yo viví. Crónicas de los frentes españoles (1936-1939). Madrid, Cuadernos para el Diálogo, 1978, pp. 74-76. 
setecientos habitantes». De acuerdo con el dato anterior, el éxodo arrancó de sus casas a más de la mitad de la población (como mínimo el 51,62\% de la misma).

Palomeque (444 habitantes en 1936). Por los informantes de La Causa General presumimos que la localidad de Palomeque, también en la ruta Toledo-Madrid, sufrió un importante descenso de población los días previos a la llegada de las tropas sublevadas. En todo caso, la ocupación del lugar se efectuó «entre el aplauso y entusiasmo de los pocos habitantes que quedaron, toda vez que la mayor parte [de los mismos] huyó ante la proximidad de las fuerzas salvadoras».

Seseña (2.100 habitantes en 1936). Acorde a La Causa, cuando el 25 de octubre de 1936 era «liberada» por las tropas nacionales, «las milicias y los elementos extremistas» de la localidad emprendían la huida en dirección a la capital de España.

Ventas de Retamosa, Las (592 habitantes de hecho, censo de 1930). Las alusiones en el informe para La Causa sobre este municipio del partido judicial de Santa Cruz de Retamar confirmarían que tenía una parte de su población evacuada. Siguiendo el citado informe, el día 16 de octubre de 1936 las tropas de la $6^{a}$ bandera de la Legión eran «recibidas con gran entusiasmo por todo el personal de derecha, pues las milicias rojas y [los] elementos de izquierda huyeron en dirección a Madrid». Tras la consulta de la entrevista realizada a su regidor, Cándido Salvador, obtenemos más detalles sobre el número de ausentes de Las Ventas que ascendía a «más de sesenta familias, de todas las edades» (350 personas, más del $60,81 \%$ del vecindario). ${ }^{49}$

Viso de San Juan, El (442 habitantes de hecho, padrón municipal de enero de 1936). Las tropas del ejército de Franco terminaron su periplo por Toledo el día 26 de octubre con la toma de esta localidad del partido de lllescas, a la derecha de la carretera Madrid-Toledo. Finalizaba así el recorrido iniciado el 28 de agosto de 1936 cuando se adentraron en la provincia por los municipios de Calzada de Oropesa y las Ventas de San Julián. La "conquista», de acuerdo con los informantes para La Causa, se efectuaba "entre el gran entusiasmo de los pocos vecinos que quedaron en el pueblo ya que la mayor parte, y casi todos rojos, huyeron antes de la entrada de las fuerzas libertadoras".

Yeles (582 habitantes en 1936). Según el regidor de Yeles, pequeño municipio del partido de Illescas, éste quedó reducido a la cuarta parte de su vecindad en la fecha de la ocupación. Es decir, se marchó del pueblo un porcentaje cercano, por exceso o por defecto, al $75 \%$ del censo (en torno a 430 personas).

49 En este supuesto utilizamos también, por excepción, un coeficiente por familia de 6 miembros porque el propio texto confirma que faltaban «más de sesenta familias» y nosotros hemos computado solamente 60 . 


\section{MADRID COMO DESTINO PROVISIONAL DE LOS REFUGIADOS DE TOLEDO}

Desde el verano de 1936 Madrid se había convertido en punto de acogida, por lo menos provisional, de los campesinos andaluces, extremeños, abulenses y toledanos que escapaban de los frentes. Las crónicas de los enviados especiales - de los medios republicanos en mayor medida - reflejaban el éxodo de los que arribaban a la capital huyendo de la guerra. Jesús Izcaray posiblemente fue el periodista más leído en la zona republicana, sus crónicas en el periódico Ahora «son la guerra» contada en directo. Sus narraciones dejaron constancia de las evacuaciones de las localidades del frente del Tajo y del destino de estos desdichados que, antes incluso de la caída de Toledo, no era otro que Madrid:

«- ¿Van ustedes a Toledo?

—No, señor —me responde la vieja—. Nosotros vamos a Madrid».

En los relatos de Izcaray aparecía siempre la capital, Madrid como primera o última parada del éxodo:

«Por las mañanas — sobre todo por las mañanas - la carretera de Madrid a Toledo —en este caso de Toledo a Madrid - se llena de carros campesinos (...) Ya había visto yo estas caravanas en Córdoba, pero aquí son más tristes, más trágicas. Van hacia Madrid y Madrid... ¡está tan cerca!»50.

La creación cinematográfica incidía también, además de la prensa, en la peregrinación campesina hacia la capital. En el reportaje pro-republicano, titulado precisamente Madrid, producido por Cinema Español y dirigido por Manuel Villegas López, los cámaras se recreaban grabando impactantes imágenes de los evacuados que huían hacia Madrid. Ancianas enlutadas vagando por los caminos, niños montados en burros, refugiados en la capital tirando de sus carros o utilizando el tranvía en una ciudad en la que se divisaban lugares tan emblemáticos como Cibeles o Gran Vía. En el documental producido por TVE, España en Guerra (19361939), encontramos asimismo instantáneas de este éxodo hacia la todavía capital de la República. ${ }^{51}$

Francisco Camba también narró en su novela Madridgrado la representación dantesca que se vivió durante esos meses en Madrid, el desfile de campesinos que despertaba la curiosidad de los viandantes: «Al llegar a La Castellana, de vuelta del

50 En septiembre de 1936 el periodista Jesús Izcaray pertenecía a la redacción del rotativo Ahora. En 1937 trabajó como redactor de la revista estampa y en el diario comunista Mundo Obrero. Algunas de sus crónicas sobre la contienda se publicaron, como ya hemos adelantado, en un libro: IZCARAY, J., Op. Cit., pp. 62 y $70-72$.

51 Madrid (1937, Manuel Villegas López). Filmoteca Española. Cinta № A-4151, 02' 30"-03' 06” (contador del video a cero en la primera imagen original). Y España en guerra (1936-1939): "No pasarán», Episodio №11 (1986, Pascual Cervera). Filmoteca Española. 
Hotel Gibraltar, me sorprendió un espectáculo que parecía una visión de otras épocas. Una fila enorme, inacabable, de carros, cubriendo el paseo hasta perderse de vista.» Esas gentes del medio rural, procedentes de las vegas del Tajo, de La Sagra, de las tierras altas de Toledo, viajaban acompañadas de todas las pertenencias que podían:

«Era la visión de un éxodo milenario. Los campesinos emigraban trayendo consigo cuanto pudo salvarse en la precipitación del naufragio. Sobre los carros veíanse colchones, muebles, baúles. Colgados de las lanzas, peroles, cestos. No se hablaban unas a otras aquellas gentes. Un fulgor de miedo en los ojos de los hombres, las mujeres con el niño dormido en un rebufo del mantón, al modo de las gitanas, sin alegrarse a la vista del término de su camino».52

En función de los acontecimientos, el ejecutivo comenzó a legislar sobre el problema originado por los desplazados, su evacuación e instalación. De esta forma, mediante una orden de Presidencia, de 5 de octubre de 1936, dictada por Largo Caballero y aparecida en la Gaceta el día 6 del mismo mes y año, ante la obligación de coordinar los esfuerzos de los organismos encargados de atender a las personas provenientes de los pueblos ocupados que habían encontrado refugio en

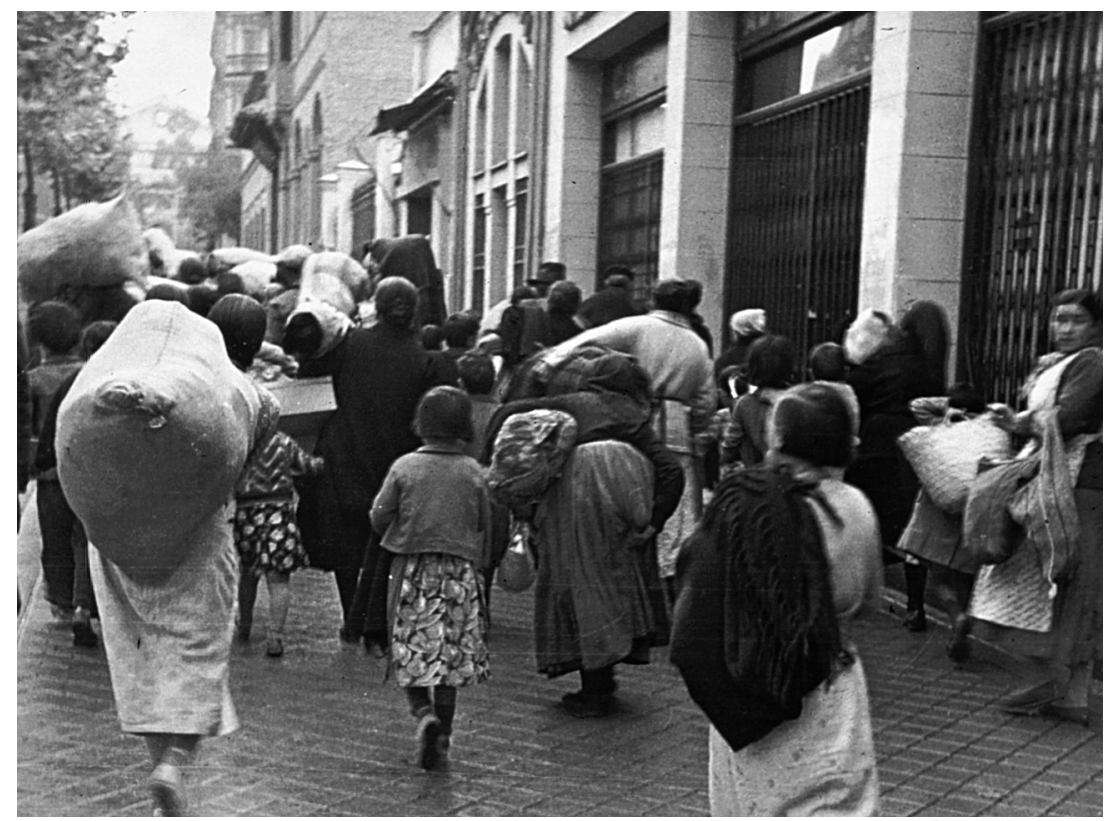

Foto N. ${ }^{\circ}$. Biblioteca Nacional. Guerra Civil. Caja F, Madrid. Evacuación. "Fugitivos en Madrid. Llegada a Madrid».

52 CAMBA, F., Madridgrado, Madrid, Ediciones Españolas, 1939, pp. 117-119. 
Madrid, se constituía en la capital de España un Comité de Refugiados de Guerra. Esta institución, presidida por el ministro sin cartera José Giral, quedaba integrada, en un principio, por miembros de instituciones oficiales, partidos políticos y sindicatos, el Comité Popular de Abastos y Socorro Rojo Internacional. El Comité tenía como función principal organizar en Madrid y su provincia todo lo relativo al alojamiento, refugio y sostenimiento de las personas emigradas de las localidades emplazadas en las líneas de combate. Este ente debía, además, regular la evacuación de Madrid a otros pueblos fieles a la República. Es decir, tenía como finalidad no solo la asistencia a los refugiados sino también la organización del traslado de los mismos a otros puntos de la geografía leal. La propia prensa de las organizaciones destacaba la importancia de la creación del citado Comité de Refugiados. ${ }^{53}$

El 13 de octubre, en una nueva orden, ante la necesidad de atender a las personas desplazadas de los pueblos que se encontraban en poder de los nacionales, se extendía la acción del nuevo Comité a todos los refugiados y emigrados de la zona ocupada, pasando a llamarse, desde ese momento, Comité Nacional de Refugiados, dependiente directamente de la Presidencia del Consejo de Ministros.

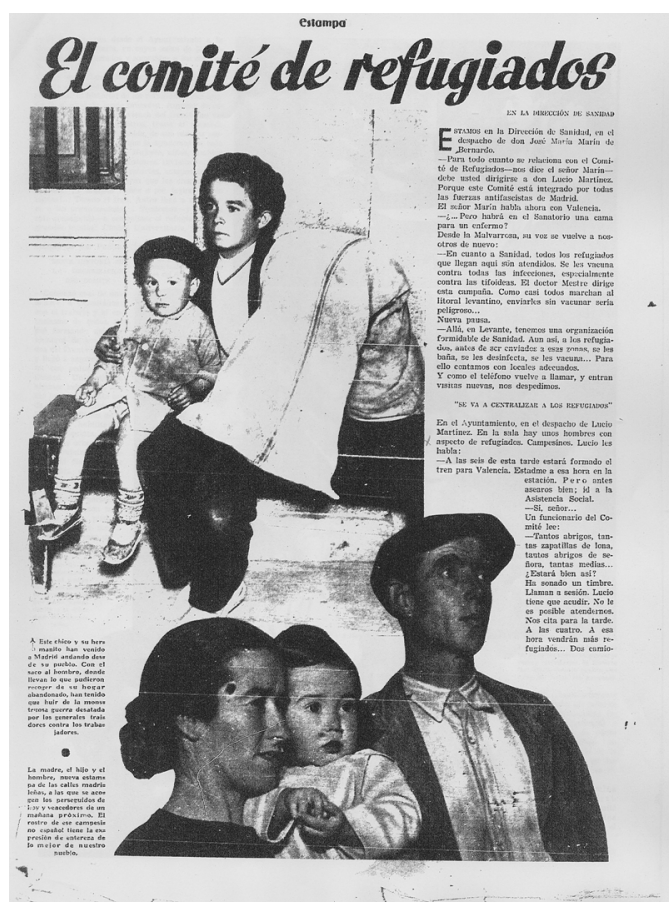

Documento N. ${ }^{\circ}$ 5. «El comité de refugiados». Estampa, n. ${ }^{\circ}$ 460, noviembre 1936.

${ }^{53}$ Consúltese GM, n²80, 6-10-36, pág. 101. Mírese igualmente Claridad, n 158, 6-10-36, pág. 2. 
Asimismo, se instauraban los Comités Provinciales y los Comités Locales de Refugiados como ramificaciones del Comité Nacional. Los Comités Provinciales, con un ámbito de actuación circunscrito al territorio de la provincia, debían organizar los Comités Locales y serían los encargados de registrar y distribuir hacia los pueblos de la provincia a los evacuados enviados por el Comité Nacional. También establecerían, de acuerdo con los Comités Locales, los medios para atender el alimento y asistencia de los refugiados, velando siempre por sus condiciones de vida. Todos los gastos corrían a cargo del Estado. ${ }^{54}$

Dichas medidas no fueron eficaces hasta noviembre de 1936. En un momento inicial, mientras estuvieron en Madrid, se determinó el alojamiento circunstancial de los refugiados en régimen colectivo, mediante establecimientos habilitados a ese fin (pisos, hoteles, centros escolares, edificios religiosos, palacios...). Uno de los pri-

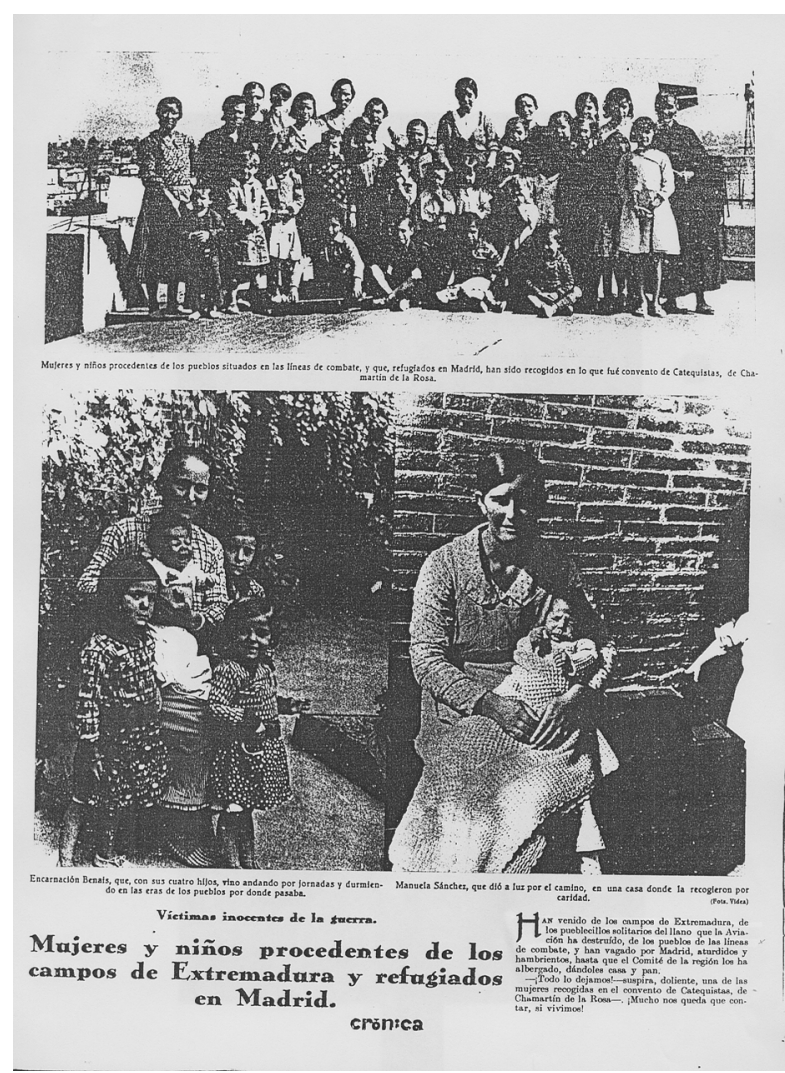

Documento N. ${ }^{\circ}$ 2. "Víctimas inocentes de la guerra. Mujeres y niños procedentes de los campos de Extremadura y refugiados en Madrid». Crónica, n. ${ }^{\circ} 362,18-10-36$.

${ }^{54}$ Consúltense las medidas citadas en $G M, n^{\circ}$ 288, 14-10-36, pág. 328; y n 291,17-10-36, pág. 372. 
meros lugares habilitados como sitio de acogida para los ocasionalmente privilegiados fue el hotel Palace.

En La forja de un rebelde de Barea podemos comprobar las pésimas condiciones higiénicas de algunos albergues colectivos, muchas veces mansiones pertenecientes a desafectos con las propiedades incautadas. Veamos el ejemplo de los evacuados de Novés viviendo en un palacete:

«Pero hay algo que yo quisiera que viera usted con sus propios ojos, porque es horrible. Es el sitio donde han metido a los más pobres del pueblo que no tenían a nadie aquí, ni dónde ir (...)

En una de las salas del palacio, una verdadera horda de mujeres, chiquillos y viejos, sucios, haraposos y malolientes, vivían en medio de un revoltijo de colchones tirados por el suelo, orinales, cacharros de cocina y piezas absurdas de mobiliario...

Mientras contemplaba aquello, el tío Juan dijo:

—Todo esto es el pueblo de Novés (...)».

No eran los únicos hacinados en el palacio, en otros cuartos habían acomodado a más toledanos de tres o cuatro pueblos vecinos, discutiendo «que si unos tienen mejor sitio que otros, o un lavabo o un retrete». ${ }^{55}$

La serie La forja de un rebelde dejó inmortalizado en la ficción televisiva el mismo drama. En la película, dirigida por Mario Camus en 1990, aparecen escenificadas de una forma fiel, espectacular y con todo lujo de detalles, las condiciones de vida de los desplazados del pueblo de Novés en el palacio de la capital de España que acabamos de describir (son instantáneas correspondientes a «La llama»). También habría que fijarse en los diálogos. ${ }^{56}$

Antes de llegar el frente a los arrabales de la capital, Leocadio Moreno y los suyos junto con otras 5 familias procedentes de El Casar de Escalona, alguna de más de 10 miembros, fueron hospedados en un piso de Pirámides. Conforme a Leocadio, la casa tenía cinco camas: «Estábamos amontonados. En los pasillos los conchones». Otros refugiados tuvieron más suerte. Francisco Jiménez Fernández y su familia — padres, tíos, abuelo y hermana — también procedentes de El Casar, residieron varias semanas en la calle doctor Fourquet 33 de Madrid. Según Francisco: «Era una casa sólo para nosotros, sin otras familias evacuadas». ${ }^{57}$

Curiosamente, varios centenares de vecinos de Quismondo estuvieron alojados en tres pisos incautados por los sindicatos en la plaza de Santa Bárbara. Los refugiados formaron una especie de pequeño pueblo dentro de Madrid, con el alcalde, los concejales, el médico... Establecieron una pequeña comunidad campe-

55 BAREA, A., Op. Cit., pp. 674-675.

56 Mírese la citada secuencia de la serie en La forja de un rebelde (1990, Mario Camus). Valladolid, 2006, DVD n³, 1h 24' 35"-1h 27' 37".

57 Leocadio Moreno y familia pasaron toda la guerra en Madrid. Sin embargo, Francisco Jiménez y sus familiares fueron evacuados a El Romeral. Entrevista realizada a Francisco Jiménez Fernández y en- 


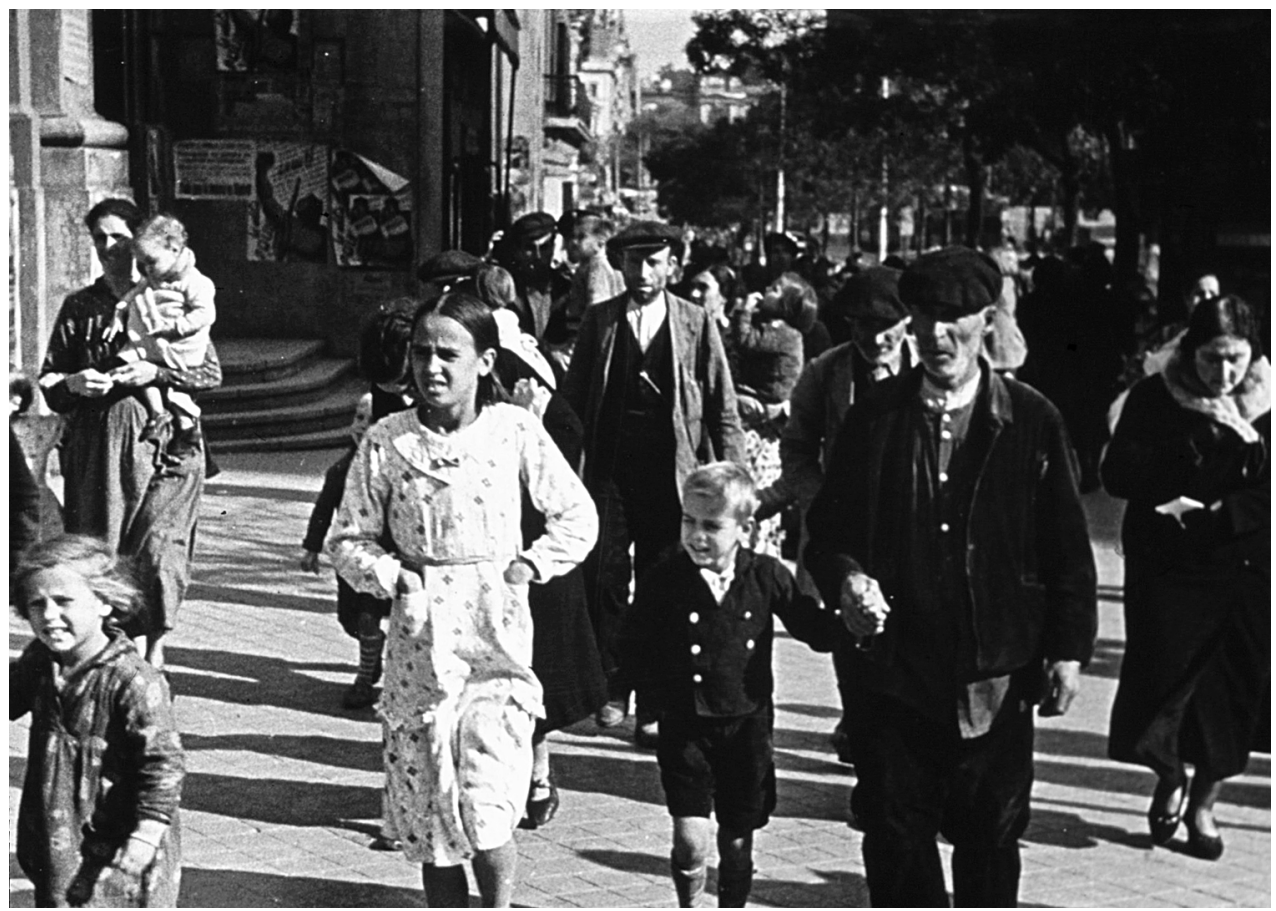

Foto N. ${ }^{\circ}$ 5. Biblioteca Nacional. Guerra Civil. Carpeta $N{ }^{\circ} 209$, Evacuaciones en diversas ciudades (Madrid).

sina, con disciplina, con turnos de lavado, limpieza y cocina. El alcalde, Emeterio García, continuó siendo el primer edil del pueblo en Madrid, atendiendo ahora los problemas en la ciudad (alojamiento, medicinas...). En Quismondo tenían organizada una comunidad y se trajeron a Madrid unas 2.000 cabezas de ganado de ésta y algunos sacos de trigo, así como varios cerdos de propiedad particular. Encerraron los animales en un campo cercano y a diario acarreaban todo lo que necesitaban. La preocupación mayor de los aldeanos era la siembra que no recogerían ese año. ${ }^{58}$

Pero muchos evadidos vivieron en la misma calle o en las estaciones de tren o de metro, perdidos, hasta que el gobierno o las milicias se hicieron cargo de ellos. Desde principios de octubre las posibilidades de instalación quedaron desbordadas:

«A los primeros que llegaban se les acomodó en casas que habían sido incautadas, los últimos tuvieron que acampar al aire libre en los paseos de la ciu-

trevista a Leocadio Moreno Santana, el 17 de julio de 2006 y el 18 de octubre de 2008 en El Casar de Escalona y Madrid respectivamente.

58 Mundo gráfico, $\mathrm{n}^{\circ}$ 1.302, 14-10-36. 


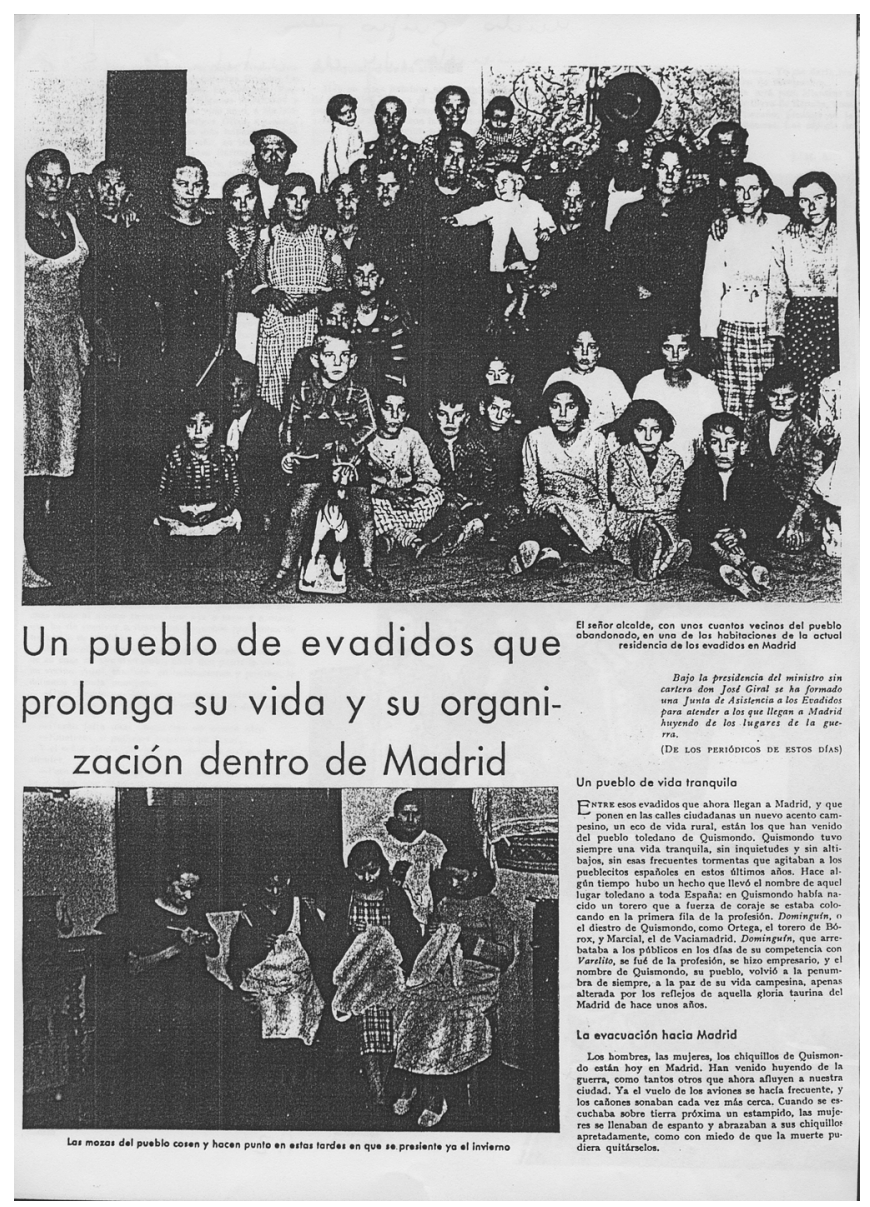

Documento $N^{\circ}$ 3. "Un pueblo de evadidos que prolonga su vida y su organización dentro de Madrid». Mundo gráfico, $n .{ }^{\circ} 1.302,14-10-36$.

dad. Se amontonaron los colchones bajo los árboles de la Castellana y Recoletos, y las mujeres guisaban en fogatas encendidas sobre las losas de las aceras. Cambió el tiempo y la lluvia torrencial comprimió a los refugiados en las casas ya llenas». ${ }^{59}$

El Parque del Retiro se llenó igualmente de familias de refugiados. Irónicamente, se llamó «El Evacuado» a la estatua de Felipe III situada en la plaza Mayor por la gran cantidad de evacuados que la rodeaban. Sobran también ejemplos de personas subsistiendo en las estaciones de tren, como la mujer toledana que no

59 BAREA, A., Op. Cit., pág. 673. 


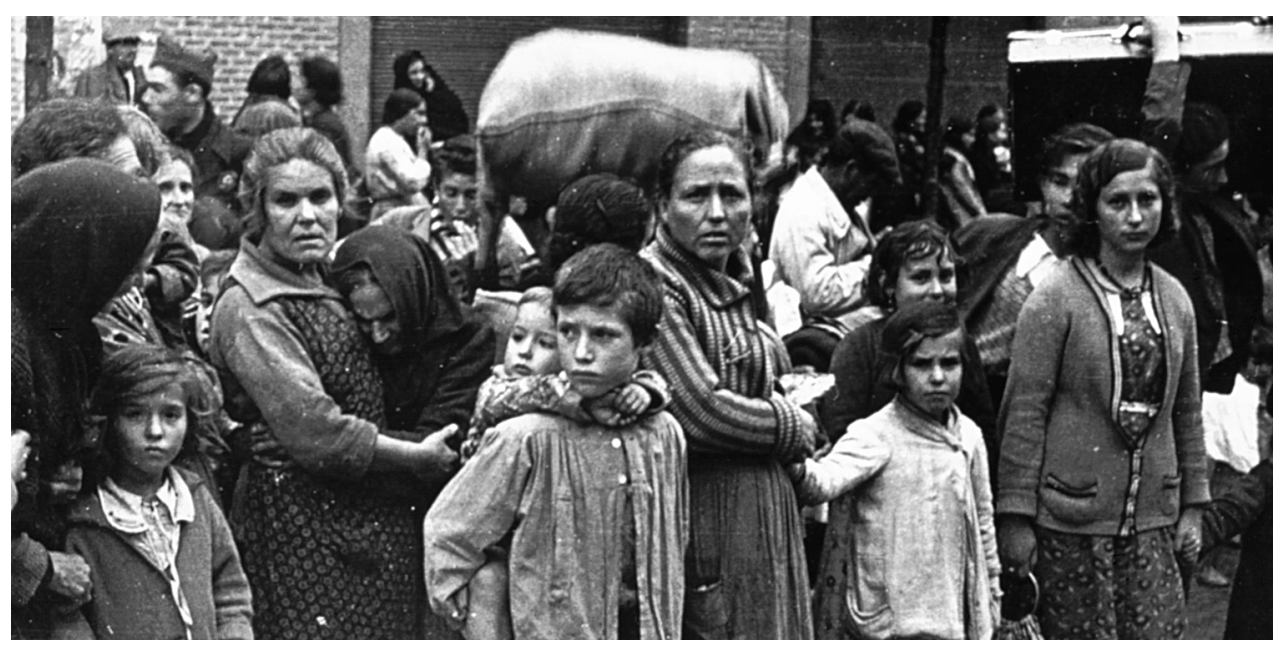

Foto N. ${ }^{\circ}$. Biblioteca Nacional. Guerra Civil. Carpeta N. ${ }^{\circ} 209$, sobre I, Evacuaciones en diversas ciudades (Madrid).

daban con ella hasta que la encontraron en la estación de las Delicias viviendo en un vagón de ferrocarril. ${ }^{60}$

El metro madrileño, inaugurado en 1919, con 34 estaciones en 1936, se convertía en domicilio provisional de los fugitivos que buscaban un lugar donde cobijarse. Un folleto de la época describía la situación de esta manera:

«La enorme población de Madrid está reducida en una parte sólo de la ciudad. El Metro está lleno de familias sin domicilio, que viven con los niños y los viejos en las estaciones, con colchones y mantas sobre el suelo. Casi todos los pisos tienen duplicados o triplicados los habitantes, y los portales y sótanos suelen estar llenos de refugiados. Esto hace necesario que la población de Madrid sea evacuada a otras regiones...».

Ante los previsibles problemas sanitarios, las autoridades llegaron a organizar un servicio de recogida e instalación de refugiados del metro para desalojar las estaciones. En esta actividad colaboraron los agentes de vigilancia y el Batallón Águilas de la Libertad. Pero a finales de 1936 muchos evadidos seguían en su empeño. Como podemos contemplar a través de las imágenes de los informativos cinematográficos de la época, el problema revestía gravedad, a Madrid habían llegado 500.000 refugiados y se cobijaban hasta 100.000 personas en los sótanos y en el metro. ${ }^{61}$

60 Consúltese Crónica, n 362, 18-10-36.

61 Sobre los refugiados en el metro léase: MOYA, A., Setenta años de Historia (1919-1989). Madrid, Metro de Madrid, 1990, pág. 184. Los refugiados en el metro también fueron captados en la cin- 
Hasta que el ejecutivo republicano no comenzó de una manera efectiva su participación oficial buscando armonizar las tareas de los distintos organismos, fueron partidos políticos, sindicatos y entidades como la Cruz Roja o el Socorro Rojo Internacional quienes se pusieron a trabajar y llevaron de forma destacada la iniciativa en las labores de evacuación y asistencia a los refugiados. De este modo, en los primeros meses del conflicto se crearon en la capital casas de acogida para hijos y huérfanos de combatientes. Una de las instituciones que fundó hogares colectivos para hijos de soldados en el Madrid de octubre de 1936 fue el Socorro Rojo Internacional. Las casas pretendían mantener a los niños alejados de los lugares de lucha y se hicieron cargo de muchos evacuados. También se ocuparon de este problema las organizaciones. Como muestra, el Hogar Infantil del $5^{\circ} \mathrm{Re}-$ gimiento de Milicias Populares establecido en la capital acogió a unos 270 chiquillos de entre seis y catorce años, la mayoría con sus padres combatiendo en los frentes pero muchos de ellos también evadidos de la guerra, básicamente del sector de Talavera. Recibían asistencia y educación. Los niños refugiados y los lugares habilitados para los mismos ocuparon un lugar principal en el aparato de propaganda republicano y fueron numerosos los carteles alusivos en ese sentido: «Los mejores Hoteles son habilitados para residencias de los niños refugiados». ${ }^{62}$

No obstante, con la evacuación programada de Madrid en el horizonte más inmediato, se hizo necesario recurrir al alojamiento familiar y así se reguló también por ley. Como las posibilidades de alojamiento de la capital quedaron prontamente rebasadas y el hacinamiento pasó a ser la nota común, mediante otra nueva orden de Presidencia, dictada el 26 de octubre de 1936, se prescribía la obligatoriedad de proporcionar alojamiento a los emigrados de los frentes de lucha, estableciendo los medios necesarios, por parte de los Comités Provinciales y Locales, para atender la alimentación y necesidades de los evacuados. La evolución del problema llevó al propio Comité a proponer la sustitución del sistema de alojamiento, hasta entonces basado en edificios incautados y dinero del Estado, y pasó a ser obligatorio para la población el hospedaje de los refugiados. Los evacuados se distribuirían entre las familias de cada localidad, de acuerdo con sus posibilidades económicas, o se instalarían en locales habilitados al efecto. En todo caso, la manutención y asistencia en las ciudades y pueblos receptores corría a cargo del Comité Local, que detentaba la potestad de establecer cuotas económicas entre los vecinos o de distribuir a los refugiados en familias para proporcionarles el albergue y la manutención. ${ }^{63}$

En función de las medidas que se fueron aplicando, en noviembre de 1936 funcionaba ya en Madrid un Comité de Refugiados integrado por distintas instituciones, sindicatos y partidos políticos. Si hasta entonces los fugitivos de las provincias cer-

ta Morir en Madrid (1963, Frédéric Rossif) en La Guerra Civil española. Documentales Inéditos, 3 5' 59 "'-36' 19".

${ }^{62}$ Consúltese Mundo gráfico, no 1.303, 21-10-36. El cartel aludido se puede ver en la página Web de UGT: http://www.ugt.es/ugtpordentro/guerra civil/cartel-122 (15-3-08).

${ }_{63} G M, n^{\circ} 301,27-10-36$, pág. 514 y n $304,30-10-36$, pág. 550. 


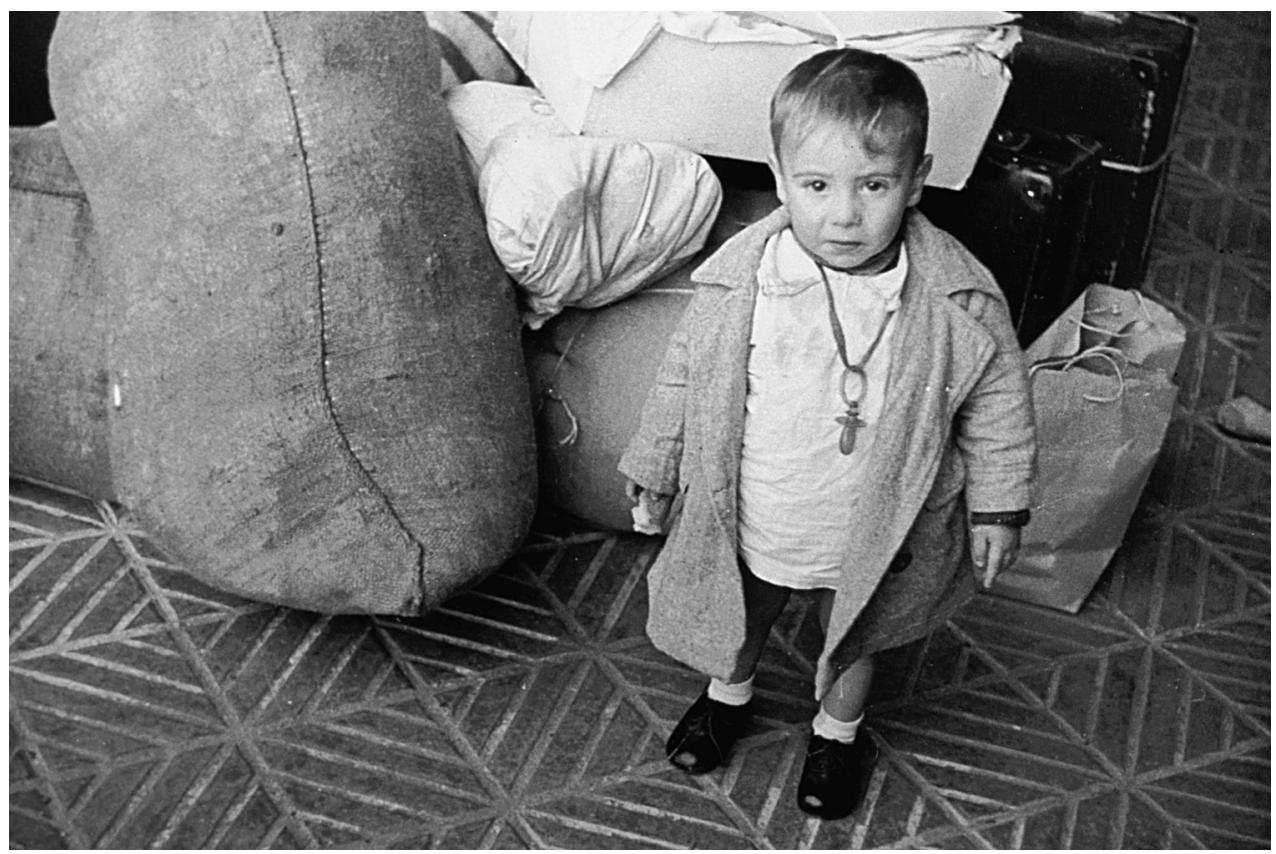

Foto N. ${ }^{\circ}$ 7. Biblioteca Nacional. Guerra Civil. Carpeta N. ${ }^{\circ} 209$, sobre I, Evacuaciones en diversas ciudades (Madrid).

canas, como Toledo, se habían refugiado principalmente en las organizaciones, ahora, con la puesta en marcha casi espontánea del Comité aludido se centralizó el refugio de los desplazados en tres grandes lugares: Ciudad Universitaria, Asistencia Social y el antiguo colegio de los Paúles (Estampa, 7 de noviembre de 1936). El Convento de la Orden de los Paúles, en la calle García de Paredes, era el Centro General de Evacuación. Los acogidos procedentes de Extremadura y Toledo, que ocupaban el pabellón número 8 de la Ciudad Universitaria, carecían muchas veces de artículos de primera necesidad y así lo demostraban varias donaciones altruistas de calzado nuevo para los mismos. Otro lugar elegido como estancia provisional era la sede de la Dirección General de Evacuación y Refugiados, en la calle Núñez de Balboa 66. No obstante, la asignación de estos centros de acogida no fue suficiente para dar un techo a tal avalancha de personas. Todavía las familias se apiñaban en las noches de otoño bajo los porches de la Plaza Mayor. Ante la situación de emergencia, el Comité Nacional de Refugiados buscó soluciones muy diversas, como la cesión de locales por parte de las legaciones extranjeras. De esta forma se dio cobijo a más de 300 desplazados en tres pisos cedidos por la Casa de Guatemala (Mundo gráfico, 16 de diciembre de 1936). ${ }^{64}$

${ }^{64}$ En los pabellones de las Facultades de la Ciudad Universitaria se habilitaron las salas quinta, sexta, séptima y octava para 800 personas; además montaron 32 duchas, cama, cocina, salón con 300 si- 
En todo caso, con la batalla de Madrid se aceleró la evacuación de la ciudad. La orden de evacuación, basada en campañas de propaganda, no iba destinada solamente a los refugiados procedentes de Andalucía, Extremadura y Castilla, que rondaban el medio millón de personas, sino también para algunos estratos de la población madrileña compuestos por mujeres, ancianos y niños. Llegaba el momento de dar salida de una manera efectiva y continuada a los refugiados y desde noviembre tomaba oficialmente las riendas de la evacuación la Junta de Defensa de Madrid por medio de la Consejería de Evacuación. Una de las funciones gubernativas principales de la Junta, que no la única, fue la evacuación de una ciudad sobrepoblada, medida necesaria para no obstaculizar su defensa. Para llevar a cabo la evacuación empezaba a funcionar el 9 de noviembre, estructurada en diferentes secciones y dependiente de la Junta, la Consejería de Evacuación con sede en la calle Núñez de Balboa 31. El consejero al frente de la misma se encargaría desde ese momento, con la colaboración de organismos e instituciones, de acoger y distribuir a zonas más seguras a la población refugiada en la capital y de poner en práctica la normativa gubernativa hasta entonces regulada. Se establecían asimismo delegaciones en los organismos que venían desarrollado, de forma más o menos improvisada, las tareas de evacuación -Comité Nacional de Refugiados, Comités de Casas, Socorro Rojo Internacional, Cruz Roja Española, Generalitat de Cataluña, Sanidad Civil y Sanidad Militar, entre otras entidades sindicales y políticas - en un intento de ejercer la coordinación de la evacuación de la población refugiada y de los propios madrileños. La Consejería sería la encargada de expedir los salvoconductos para salir de Madrid en evacuaciones colectivas, previo aval de alguna organización política, sindical u oficial. Además, para la evacuación del interior de la capital, la Junta de Defensa de Madrid se apoyaría, con la colaboración del Socorro Rojo Internacional, en los Comités de Casa del Frente Popular (El Sindicalista, 14 de noviembre de 1936) y en el Comité Nacional de Refugiados para la evacuación exterior. La organización de la evacuación se complicaría nuevamente con el nacimiento el día 13 de noviembre de dos nuevos organismos concebidos por la Consejería: El Comité de Auxilio del Niño y el Consejo de Evacuación, que no llegaron a publicarse en Boletín aunque si en la prensa ( $A B C$, Madrid, 24 de noviembre de 1936). ${ }^{65}$

En definitiva, entre octubre de 1936 y febrero-marzo de 1937, se efectuaron interminables traslados de población hacia la retaguardia republicana cercana - ac-

\footnotetext{
llas, taller de costura y menaje. Un contingente de refugiados procedentes del frente de Extremadura - que al principio incluía Toledo- estaba alojado en la Ciudad Universitaria. Léase sobre ello Estampa, no 460, 7-11-36. A estos efectos, consúltese en Archivo Regional de Madrid (ARM). SIG MC 009516 (1936-1937), Libro de Actas de la Comisión Gestora (LACG), sesión del 14-10-36. Ante el colapso poblacional, la Legación de Guatemala en Madrid había cedido al Comité de Refugiados varios pisos para los evacuados y todavía en diciembre albergaba a más de 200 personas en sus techos. Mírese Mundo gráfico, no 1.311, 16-12-36.

65 La Junta tomaba la decisión de dirigir exclusivamente la evacuación para intentar terminar con «la confusión que existe» por la intervención de diversos organismos. Así consta en el Acta de la Junta de Defensa de Madrid, sesión del 8-11-36. Véase ARÓSTEGUI, J., y MARTíNEZ, J. A., Op. Cit., pp. 171 175 y 293. En prensa: El Sindicalista, 14-11-36 y $A B C$ (Madrid), 24-11-36.
} 


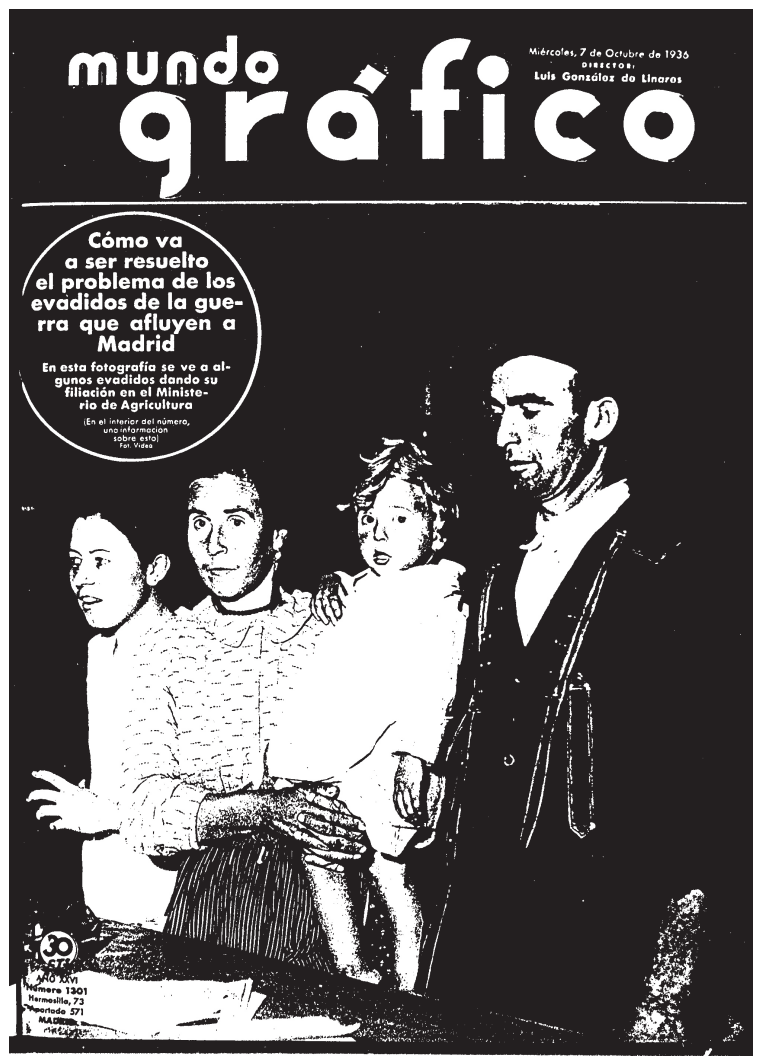

Documento N. ${ }^{\circ}$ 4. "Cómo va a ser resuelto el problema de los evadidos de la guerra que afluyen a Madrid». Mundo gráfico, n. $1.301,7-10-36$, portada.

tual Castilla-La Mancha- y la zona mediterránea, en especial los pueblos costeros de Murcia, Alicante, Valencia, Tarragona y Gerona. En estos desplazamientos estuvieron implicados muchos de los refugiados toledanos que habían llegado precipitadamente a la capital desde el verano de 1936. Capítulo aparte merece el fenómeno de los niños evacuados por la guerra en el que se vieron inmersos también los chiquillos de Toledo. Las autoridades realizaron campañas en prensa, radio, cine y carteles para difundir las ventajas de la evacuación, aunque los resultados, sobre todo por la estabilización del frente de Madrid, no fueron los esperados.

\section{CONCLUSIONES}

A partir del 28 de julio de 1936, con la llegada de los primeros aviones alemanes a Marruecos, se iniciaba la fase dinámica de la guerra civil española, denominada «la guerra de las columnas», etapa que cursó como una campaña relámpa- 
go por el rápido avance del ejército nacional a través de Andalucía, Extremadura y el valle del Tajo. Desde el día 28 de agosto, fecha de la entrada de las columnas africanas en las comarcas occidentales de Toledo, hasta la llegada de las mismas a la provincia de Madrid, se ocuparon un total de 116 localidades de los partidos de Oropesa, Puente del Arzobispo, Talavera, Escalona, Torrijos, Santa Cruz de Retamar e Illescas. Según cambiaban los frentes, los habitantes abandonaban los pueblos de forma improvisada. Los episodios militares desataron no solamente un éxodo de personas sino también de las instituciones, y así ocurrió con los organismos de Toledo y sus empleados.

El carácter precario de las fuentes para el estudio de los desplazados de las localidades afectadas por el avance del frente nos haría abandonar, por el momento, toda pretensión en torno a una cuantificación completa y total de los toledanos ausentes de sus pueblos. En cualquier caso, de acuerdo con la documentación consultada, en los primeros meses de la guerra, todavía sin ajustar los saldos migratorios, el porcentaje de desplazados estaría comprendido, siempre de manera aproximada, entre el impactante $96,43 \%$ de Maqueda y cifras inferiores al $5 \%$ en algunos supuestos, pero faltarían todavía noticias de municipios con una importante población censada en 1936, que podrían incrementar, en mucho, las cifras absolutas del éxodo poblacional de Toledo como consecuencia de la guerra.

Ajustado a los datos anteriores, pueblos como Illescas, Maqueda, Quismondo, Santa Olalla o Yeles perdieron al menos tres cuartas partes de su vecindario. Municipios como Alcabón, Añover de Tajo, Arcicóllar, Carmena, Carriches, Cobeja, Erustes, Fuensalida, Olías del Rey, Talavera de la Reina o Las Ventas de Retamosa superaban la proporción del $40 \%$. Localidades como El Casar de Escalona y Gamonal tuvieron caídas demográficas cercanas a esta cifra. Por debajo del $30 \%$ cursaron el resto de pueblos estudiados: Alameda de la Sagra, Almorox, El Carpio de Tajo, Escalonilla, Navalcán, Pelahustán, La Puebla de Montalbán y El Real de San Vicente, con una horquilla muy amplia que oscilaría entre el 4 y el $30 \%$.

La afloración de nuevos datos ayudará a completar los resultados parciales, en ocasiones poco concretos y seguramente infravalorados, porque tenemos constancia de que a la entrada de las tropas de Marruecos en Oropesa «una gran parte de sus habitantes había huido con antelación»; en Gerindote «muchas familias» se marcharon; Novés «estaba casi vacío»; en Torrijos «falta casi todo el pueblo»; en Camarena «la guerra marcó su garra negra arrancando más de la mitad» de su vecindario; Cedillo del Condado «ahora apenas si cuenta la mitad» de sus habitantes... Como vemos, muchas referencias explícitas sobre la población ausente e indicios generales de posibles desplazados en pueblos importantes, con un censo relevante en 1936. En todo caso, los datos de que disponemos elevarían la merma inicial a valores superiores al $40 \%$ de la población de los pueblos. La mayoría de estos desplazamientos se llevaron a cabo los días previos a la ocupación y el componente principal de los afectados estaría compuesto por campesinos, sobre todo ancianos, mujeres y niños, pero también por hombres de mediana edad. 
La tónica general al presentarse las tropas del ejército de África en los principales núcleos estratégicos, sobre todo los pueblos enclavados en los cruces de las comunicaciones radiales con las de circunvalación, era que se encontraban «medio vacíos» o prácticamente "deshabitados». El número de evacuados de los municipios situados en la ruta de las operaciones principales de la «Columna Madrid», con fuertes combates o con resistencia miliciana, fue superior en comparación con los pueblos del interior provincial, más alejados de las principales vías de comunicación y relativamente más tranquilos. El volumen y la localización de los desplazados de Toledo se convierten en dos cuestiones básicas.

Aunque de la consulta de varias fuentes esenciales para este trabajo se podría inferir lo contrario, las imágenes, las crónicas escritas y los testimonios de algunos de los afectados, debidamente contrastados, parecen demostrar que, sin descartar supuestos de amenazas o la propaganda realizada desde las instituciones y las organizaciones republicanas, el miedo a la conflagración, la actitud de las tropas moras y el temor a la represión fueron los factores más determinantes del éxodo. Además, en esta fase de la guerra la evacuación fue espontánea y desorganizada, prácticamente sin directrices políticas.

Entre Talavera y Toledo los de África utilizaron la razia tras la conquista como habían venido haciendo desde Andalucía (tenemos, entre otros, los ejemplos de Talavera, El Casar de Escalona o Toledo). Si bien la violencia inicial parece que disminuyó a partir del 28 de septiembre, los movimientos migratorios ya no se frenaron. Lógicamente, antes de la llegada de los nacionales ya habían huido las personas más implicadas con la República, pero la mayoría de los desplazados eran campesinos, generalmente sin adscripción política o sindical.

Desde el verano de 1936, el trayecto militar del ejército nacional por tierras de Andalucía, Extremadura y Toledo provocó un trasiego de personas con la capital de España como destino primordial. En los últimos días de septiembre los evacuados eran la estampa cotidiana de las calles, de las estaciones y de los refugios habilitados en Madrid. Las autoridades no podían ocultar ya el fracaso del efectivo defensivo ideado por los estrategas republicanos. En estos primeros meses la tragedia de los refugiados se expresó de muy diversas formas. Destacados periodistas, importantes novelistas, las productoras cinematográficas más importantes de España y del mundo... inmortalizaron los momentos más emotivos de las evacuaciones espontáneas de los campesinos de los pueblos de Toledo en su huida hacia Madrid. Todos coincidieron en destacar la odisea vivida por los toledanos.

Como la asistencia a los refugiados carecía de estructura al comienzo de la contienda, hasta octubre de 1936 no se comenzó a legislar sobre la misma con la creación del Comité de Refugiados de Madrid. El citado Comité se transformó posteriormente en Comité Nacional de Refugiados, con Comités Provinciales y Comités Locales de Refugiados en su organigrama, todos ellos dependientes de la Presidencia del Consejo de Ministros. A pesar de las medidas, durante los mo- 
mentos iniciales la labor desarrollada por sindicatos y partidos políticos resultó primordial.

Al principio, los desplazados se instalaron en locales, pisos y edificios improvisados, muchas veces en pésimas condiciones, pero no era suficiente el régimen colectivo para alojar tal concentración humana. Las principales calles, plazas y parques así como los andenes, vestíbulos y pasillos del metro de Madrid se transformaron en el lugar de acogida de muchos toledanos. Cuando las posibilidades de alojamiento quedaron desbordadas se empezó a recurrir al hospedaje y la manutención familiar, y en esa línea caminó la legislación republicana.

La creación de la Junta de Defensa de Madrid el 7 de noviembre de 1936 y de la Consejería de Evacuación dependiente de ella dos días después, fueron claves en la activación de la evacuación programada de una ciudad saturada con la llegada de miles de desplazados.

Desde octubre de 1936 los refugiados se habían convertido ya en un serio problema para la capital. En los últimos meses del año las colas para comprar se convirtieron en la imagen habitual. No cesaban las caravanas de fugitivos y había que descongestionar Madrid, que se preparaba para un asedio de duración incierta. Se iniciaba la evacuación de la población a zonas más tranquilas de la geografía republicana. Los destinos de los toledanos fueron los pueblos leales de la provincia de Madrid, el sur de Toledo, el resto de provincias de la actual Castilla-La Mancha, Levante y Cataluña. Desde noviembre, las autoridades republicanas, encabezadas por la Consejería de Evacuación dependiente de la Junta de Defensa, procedieron ya de una manera sistemática a distribuir a los refugiados, y a los propios madrileños, por Levante y Cataluña. No obstante, muchos toledanos, aprovechando vínculos familiares o de amistad, lograron quedarse en Madrid.

A pesar de todo, hasta finales de 1936 el gobierno de la República fue siempre a remolque en lo que se refiere a la asistencia a los refugiados y evacuados. Durante estos seis meses, la iniciativa la tuvieron los partidos políticos y los sindicatos, especialmente las federaciones dependientes de UGT. 
Estadillo N. ${ }^{\circ}$. Pérdida poblacional de los municipios situados al norte del río Tajo como consecuencia de la guerra (1936) (1)

\begin{tabular}{|c|c|c|c|c|}
\hline \multirow[b]{2}{*}{ Municipios } & \multicolumn{3}{|c|}{ Población de hecho } & \multirow{2}{*}{$\begin{array}{c}\text { Ausentes (\%) } \\
1936\end{array}$} \\
\hline & $\begin{array}{c}\text { Censo } \\
1930\end{array}$ & $\begin{array}{c}\text { Padrón } \\
1936\end{array}$ & $\begin{array}{l}\text { Causal } \\
\text { General }\end{array}$ & \\
\hline $\begin{array}{l}\text { Alameda de la Sagra } \\
\text { Alcabón } \\
\text { Almorox } \\
\text { Añover de Tajo } \\
\text { Arcicóllar } \\
\text { Carmena } \\
\text { Carpio de Tajo, El } \\
\text { Carriches } \\
\text { Casar de Escalona, El } \\
\text { Cobeja } \\
\text { Erustes } \\
\text { Escalonilla } \\
\text { Fuensalida } \\
\text { Gamonal } \\
\text { Illescas } \\
\text { Maqueda } \\
\text { Navalcán } \\
\text { Olías del Rey } \\
\text { Pelahustán } \\
\text { Puebla de Montalbán, La } \\
\text { Quismondo } \\
\text { Real de San Vicente, El } \\
\text { Santa Olalla } \\
\text { Talavera de la Reina } \\
\text { Ventas de Retamosa, Las } \\
\text { Yeles }\end{array}$ & 1.657 & $\begin{array}{r}3.011 \\
793 \\
2.070 \\
4.245 \\
921 \\
1.956 \\
635 \\
558 \\
3.702 \\
5.131 \\
1.778 \\
2.228 \\
\\
3.641 \\
\\
1.491 \\
7.593 \\
2.100 \\
2.140\end{array}$ & 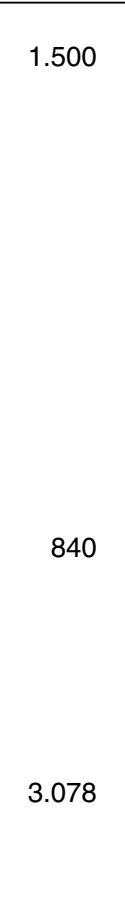 & $\begin{array}{r}12,07 \\
56,67 \\
16,11 \\
66,68 \\
50,00 \\
40,00 \\
29,45 \\
43,00 \\
30,67 \\
31,50 \\
50,18 \\
20,00 \\
50,67 \\
32,06 \\
80,00 \\
96,43 \\
3,29 \\
51,62 \\
17,44 \\
22,39 \\
86,90 \\
4,53 \\
87,00 \\
66,38 \\
60,81 \\
75,00\end{array}$ \\
\hline
\end{tabular}

(1) Solamente hemos incluido en la tabla los pueblos de los que disponemos de datos de ausentes. 